\title{
Regime shifts in marine ecosystems of the North Sea and Wadden Sea
}

\author{
Mariska Weijerman ${ }^{1}$, Han Lindeboom ${ }^{1, *}$, Alain F. Zuur ${ }^{2}$ \\ ${ }^{1}$ Royal Netherlands Institute for Sea Research, PO Box 597, 1790 AD Den Burg, Texel, The Netherlands \\ ${ }^{2}$ Highland Statistics Ltd., 6 Laverock Road, Newburgh AB41 6FN, Aberdeenshire, UK
}

\begin{abstract}
Wide-scale and sudden shifts in several biological and environmental systems of NW Europe have been reported in recent years, and attributed to a range of factors, both climatic and anthropogenic. To examine whether there is any evidence of coinciding region-wide environmental shifts, we gathered existing long-term data series on a wide range of physical and biological parameters from the 1960s to the present and, following the methods of a similar recent study on North Pacific regime shifts, we analysed the data using principal component analysis and regime shift analysis to identify the extent and timing of regime shifts in NW Europe. The end-point of a regime (i.e. the year) was determined using a sliding window in regime shift analysis. Additionally we applied chronological clustering to the (1) combined data, (2) biological data and (3) environmental data. In all 3 cases, the same regimes were identified. Our results indicate that substantial regime shifts occurred in the marine ecosystem in 1979 and 1988 and perhaps also in 1998, although results were less clear-cut in the latter case. These regime shifts were most evident among the biological data series, but they appeared to have been triggered by earlier shifts in a number of environmental factors. Salinity and weather conditions played an important role in the 1979 shift, while in the 1988 shift, temperature and weather conditions were the predominant factors. Our results confirm those of the North Pacific study, with concomitant changes in physical and biological indices. This indicates a shift in climate-ocean interactions throughout the entire temperate zone of the Northern Hemisphere.
\end{abstract}

KEY WORDS: North Sea · Regime shifts · Long-term data series · Principal component analysis · Regime shift analysis $\cdot$ Chronological clustering

\section{INTRODUCTION}

Numerous publications have documented dramatic changes in marine ecosystems of the NW European shelf during recent decades (Appendix 1; www.intres.com/journals/weijerman_appendix.pdf). Substantial variability has been documented in hydrographic/ oceanographic relations by Svendsen \& Magnusson (1992) and Ellet \& Blindheim (1992), in the biomass and diversity of phyto- and zooplankton communities by Southward et al. (1995) and Edwards et al. (2002), in zoobenthic communities by Kröncke et al. (1998), in fish communities by Reid et al. (2001a), in bird communities by Swennen (1991) and in seal populations by Reijnders \& Brasseur (2003). Several of these researchers have reported sudden (from one year to the next) changes around the late 1970s and late 1980s. Reid et al. (2001b) also reported a possible third shift in 1998. These apparent shifts have been linked with climate-ocean variability such as the large-scale salinity anomaly in 1978 (Dickson et al. 1988), severe winters with low temperatures and high storm frequencies (Beukema 1990), and a drastic reduction of the Atlantic inflow in the late 1970s (Svendsen \& Magnusson 1992), as well as with anthropogenic factors such as eutrophication and fisheries (OJaveer 1996). More recently, biotic changes have been linked with atmospheric modes, in particular the North Atlantic Oscillation (NAO) (Rogers 1984), which oscillates between positive and negative indices caused by a change in pressure difference between Iceland and the Azores. Hare \& Mantua (2000) defined the sudden changes from one 
stable condition to another as regime shifts, a term we will use in this study.

A fundamental question in ecology is what factors drive or trigger changes in biological processes. In the late 1990s, a European project DYNAMO (Dynamics through Natural and Anthropogenic causes of Marine Organisms) was launched with the aim of improving the understanding of the natural dynamics of marine ecosystems by analysing long-term environmental and ecological data sets. The project focused on marine ecosystems of NW Europe. Results from this project indicated that large-scale changes at various levels of the marine ecosystems were taking place, and it was concluded that they were likely to have been triggered by a shift in the state of the atmosphere-ocean climate system (Philippart et al. 2000). In a different approach to the same broad questions, Ottersen et al. (2001) carried out an extensive literature review to assess the likely impact of the NAO on marine and terrestrial processes. They concluded that the NAO has a strong influence on ecological dynamics and that it causes diverse responses in ecological processes, ranging from the timing of reproduction to spatial distribution of biological communities. Scheffer et al. (2001) focused on the role of biotic interactions in driving oceanic community dynamics, and speculated that disruption of stable states by natural or anthropological events can cause shifts in species abundance on multiple trophic levels. Lindeboom et al. (1995) pointed out that marine ecosystems show large interannual and interdecadal variations and posited the hypothesis that the North Sea ecosystem switched from a benthic system to a pelagic system in 1978, and that a feedback mechanism acted to maintain it in that new stable state. The switch they described also led to changes in the biological and geochemical nutrient cycles, and appears to have been triggered by changes in the macro- and micronutrient ratios in incoming water, coinciding with the salinity anomaly. Bergman \& Lindeboom (1999) wondered if the numerous atmospheric and climactic cycles which have been documented (Burroughs 1992) were reflected in the evident substantial variability of marine ecosystems. They considered the potential importance of the Hale cycle of $22 \mathrm{yr}$, the $11 \mathrm{yr}$ sunspot cycle, and the $18.6 \mathrm{yr}$ nodal cycle.

There is therefore a substantial body of evidence indicating that regime shifts occurred in the North Atlantic in the late 1970s and late 1980s, and at least 1 other study that indicates that a change occurred in 1998. The direct cause of these shifts is difficult to determine, but there are grounds for suspecting that they might be linked with climate-ocean variability. A similar study to the present one was recently carried out by Hare \& Mantua (2000) in the North Pacific. They reported evidence of regime shifts in 1977 and 1989 among a diverse set of 29 physical and 71 biological time series. In this study, we explore the timing of, and apparent cues for, sudden changes in ecological and environmental systems of the wider North Sea. Specifically, we have collected a wide range of ecological and environmental data sets from the North Sea and Wadden Sea ecosystems covering the years between 1960 and 2002. Our principal aim was to explore evidence for coincident shifts in environmental and ecological variables and to identify the years in which the largest shifts occurred. We have also attempted to identify explanatory patterns or factors by determining the physical/environmental variables that appear to contribute most to such shifts.

\section{MATERIALS AND METHODS}

We gathered long-term time series directly from scientists, from published reports, and from the Internet. Our criteria for selecting appropriate data sets were:

- Time series covering at least the last $30 \mathrm{yr}$, preferably 40 yr

- Large spatial spreading, i.e. including data from the whole North Sea, Skagerrak, German Bight and Wadden Sea

- No or few missing values in the data set

- No obvious anthropogenic cause for sudden changes in a data series

- Time series comprising multiple trophic levels and different environmental variables

With these criteria we aimed to select a diverse set of around 100 variables. Fig. 1 shows the spatial distribution of the variables in the North Sea and Dutch Wadden Sea. Variables are numbered as in Table 1. The availability of data sets meeting all criteria limited our study to 78 data sets: 28 environmental data sets comprising atmospheric and oceanic variables, and 50 biological time series representing a very wide range of marine organisms from phytoplankton to top-level predators. Appendix 2 (www.int-res.com/journals/ weijerman_appendix.pdf) presents the time series used and their sources, and explains why certain data sets were excluded from some analyses.

From the literature it became clear that climate conditions in winter months have the greatest influence on biological processes (e.g. Beare \& McKenzie 1999, Beukema et al. 2002) and we therefore included mostly winter averages for the physical parameters. For biological variables we used either spring/summer means or annual averages. None of the data sets have been smoothed, other than taking the seasonal or annual average. To reduce the effect of outliers and to 
linearize the relationships between the biological variables, a logarithmic transformation was applied to all biological variables and 2 environmental time series (summer storms and the number of days with frost).

Following the approach of Hare \& Mantua (2000) we analysed the data using 2 statistical methods: principal component analysis (PCA) and regime shift analyses (RSA) as employed by Ebbesmeyer et al. (1991).

The PCA was used to determine a general pattern in the time series. As our original data series are measured in different units and have a wide range in variation, the PCA was based on the correlation coefficient instead of the covariance coefficient (Jolliffe 2002). We concentrated on 3 outputs of PCA: (1) the principal components (PCs, also called the PC scores or eigenvectors) which, plotted against time, show the underlying pattern of a specific $\mathrm{PC}$ and thus if and when a sudden change occurred; (2) loadings, which show the extent to which original variables are related to PCs; and (3) the eigenvalues, which show how much of the variance in the total data is explained by each PC. We wanted to account for at least $40 \%$ of total variation in the original variables and based on that we determined the number of PCs to use in each case.

Because some of the biological time series only started in the 1970 s, we first wanted to know to what extent the PCA output would be influenced by those shorter time series. Missing values in PCA are replaced by column (= variable) averages, resulting in less variation in the data. We did this by comparing (1) the PCA results from the full biological data set (48 variables, 42 years), with (2) the PCA results from all biological data sets but starting in 1970, with (3) the PCA results of only those data sets with not more than 10 missing values (resulting in 34 data sets), and with (4) the PCA results of the same 34 time series but now only taking into account the years 1970 to 2002. The resulting patterns of the PCs of all 4 PCA were very similar; only the amount of variance explained by the first 2 PCs differed by up to $6 \%$. As we were most interested in the underlying pattern of the whole ecosystem and expected the first shift in the late 1970s, we decided to continue further analyses with the complete data set but starting in 1970, as these seemed to be the most robust data. In order to compare these PCA results with the environmental time series, we used only the data from 1970 onwards for all variables.

The second statistical model is the so-called step analysis or regime shift analysis (Ebbesmeyer et al. 1991). Based on the results of the PCA we used this method to identify the year(s) in which largest shifts occurred by calculating step-magnitude for 5 con-

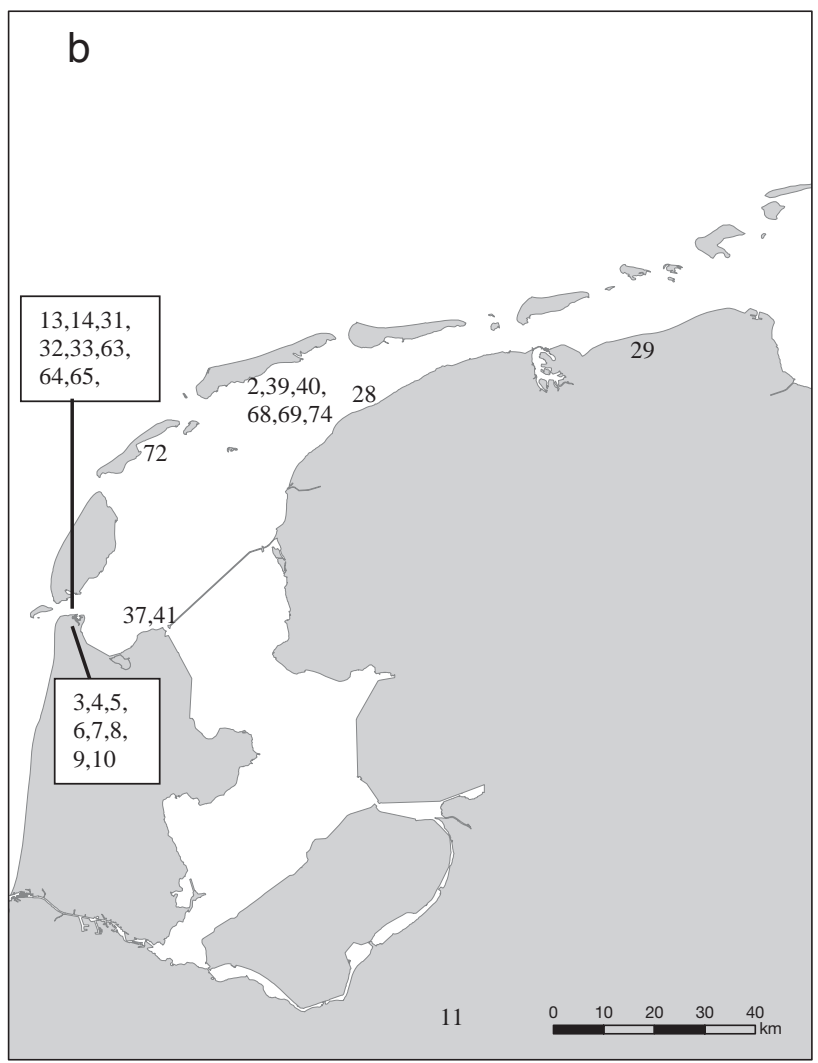

Fig. 1. Spatial distribution of sample locations in (a) North Sea and (b) Dutch Wadden Sea. Variables numbered as in Table 1 
Table 1. Differences of mean values of individual time series between 2 regimes (see Step 3 in regime shift analysis in 'Materials and methods'). 1979 change is difference between 1969 to 1978 (Regime I) and 1980 to 1989 (Regime II); 1988 change is difference between 1978 to 1987 (Regime II) and 1989 to 1998 (Regime III). Differences only calculated when >5 yr before and >5 yr after year of change for any given time series. Detailed description, pattern of each time series and its source are given in Appendix 2. NCP: Netherlands Continental Plateau

\begin{tabular}{|c|c|c|c|c|}
\hline $\begin{array}{l}\text { Var. } \\
\text { no. }\end{array}$ & Abbreviation & Description & $\begin{array}{l}1979 \text { change } \\
\text { Mean of } \\
\text { Regimes I-II }\end{array}$ & $\begin{array}{c}1988 \text { change } \\
\text { Mean of } \\
\text { Regimes II-III }\end{array}$ \\
\hline 1 & NAOWIN & North Atlantic Oscillation winter index (Dec, Jan, Feb, Mar average) & 0.68 & 0.77 \\
\hline 2 & WADMHT & Annual mean high tide in Wadden Sea & 1.44 & 0.07 \\
\hline 3 & WINDIR & $\begin{array}{l}\text { Prevailing wind direction in degrees }\left(360^{\circ}=\mathrm{N}, 270^{\circ}=\mathrm{W}, 180^{\circ}=\mathrm{S},\right. \\
\left.90^{\circ}=\mathrm{E}\right) \text { in De Kooy (North Holland) }\end{array}$ & 0.77 & 0.20 \\
\hline 4 & WINSPE & Mean annual wind speed in De Kooy & -1.26 & -0.47 \\
\hline 5 & AIRTEMP & Mean annual air temperature in De Kooy & -0.34 & 1.56 \\
\hline 6 & SUNSHI & Total annual sunshine duration in De Kooy & -0.49 & 1.81 \\
\hline 7 & PRECIP & Total annual precipitation amount in De Kooy & 1.05 & -0.25 \\
\hline 8 & SAP & Mean annual surface air pressure in De Kooy & 0.25 & 1.12 \\
\hline 9 & CLOUD & Mean annual cloud cover in De Kooy & 0.16 & -0.46 \\
\hline 10 & Log_SUMSTORM & $\begin{array}{l}\text { No. of days in summer (Jun, Jul, Aug) with wind speed }>10.8 \mathrm{~m} \mathrm{~s}^{-1} \text { or } \\
>6 \text { Beaufort }\end{array}$ & -0.77 & -0.24 \\
\hline 11 & Log_V_Ynsen & $\begin{array}{l}\text { Total days with frost (i.e. min. temperature }<0^{\circ} \mathrm{C} \text { ) from Nov to Mar in } \\
\text { De Bilt (Netherlands) }\end{array}$ & 0.05 & -0.99 \\
\hline 12 & ASTCE & Average surface air temperature in central England & 0.09 & 2.88 \\
\hline 13 & WZTEMPWIN & $\begin{array}{l}\text { Mean winter sea-surface temperature at Marsdiep, Wadden Sea (Dec, } \\
\text { Jan, Feb, Mar) }\end{array}$ & 0.02 & 1.02 \\
\hline 14 & WZSAL & Mean annual sea-surface salinity at Marsdiep, Wadden Sea & -1.47 & 0.93 \\
\hline 15 & SSN & Sunspot no. & 0.61 & -0.17 \\
\hline 16 & EA & East Atlantic teleconnection pattern index (Sep to Apr) & 1.65 & -0.01 \\
\hline 17 & EA_JET & East Atlantic Jet pattern index (Apr to Aug) & 0.87 & 1.19 \\
\hline 18 & SCAN & $\begin{array}{l}\text { Scandinavian teleconnection pattern, indices all months except } \\
\text { Jun and Jul }\end{array}$ & -0.09 & -0.63 \\
\hline 19 & WAVE_WIN & Wave height (m) at Buoy K13 in North Sea (winter average) & & -0.16 \\
\hline 20 & SOLCON & $\begin{array}{l}\text { Solar constant derived from solar irradiance with interpolated } \\
\text { monthly values }\end{array}$ & 2.94 & 1.23 \\
\hline 21 & SST_NS & $\begin{array}{l}\text { Annual average sea-surface temperature in North Sea (51 to } 62^{\circ} \mathrm{N} \text {, } \\
\left.4^{\circ} \mathrm{W} \text { to } 12^{\circ} \mathrm{E}\right)\end{array}$ & -0.21 & 2.11 \\
\hline 22 & SST_WIN & $\begin{array}{l}\text { Mean winter sea-surface temperature in North Sea }\left(50 \text { to } 60^{\circ} \mathrm{N} \text {, }\right. \\
\left.0 \text { to } 4^{\circ} \mathrm{E}\right)(\mathrm{Jan}, \text { Feb, Mar) }\end{array}$ & -0.64 & 1.89 \\
\hline 23 & SST_SUM & $\begin{array}{l}\text { Mean summer sea-surface temperature in North Sea }\left(50 \text { to } 60^{\circ} \mathrm{N} \text {, }\right. \\
\left.0 \text { to } 4^{\circ} \mathrm{E}\right) \text { (Jun, Jul, Aug) }\end{array}$ & -0.07 & 1.48 \\
\hline 24 & SLP & Mean sea-level pressure in North Sea $\left(0\right.$ to $6^{\circ} \mathrm{E}, 50$ to $\left.60^{\circ} \mathrm{N}\right)$ & & -0.17 \\
\hline 25 & N/P_JFM & $\begin{array}{l}\text { Nitrate-phosphate relation in southern North Sea (Jan, Feb, Mar) } \\
\left.\text { (ICES Quadrant IVb } 50 \text { to } 55^{\circ} \mathrm{N}, 0 \text { to } 5^{\circ} \mathrm{E}\right)\end{array}$ & 1.24 & 1.31 \\
\hline 26 & SAL_NS & $\begin{array}{l}\text { Annual average sea-surface salinity in southern North Sea } \\
\left.\text { (ICES Quadrant IVb } 50 \text { to } 55^{\circ} \mathrm{N}, 0 \text { to } 5^{\circ} \mathrm{E}\right)\end{array}$ & -1.43 & -0.91 \\
\hline 27 & WINSP_NS & Annual mean wind speed $\left(\mathrm{m} \mathrm{s}^{-1}\right)$ over North Sea & 1.33 & 1.03 \\
\hline 28 & FRMARSH & Outer border marshland area along coast of Friesland (m from dyke) & 5.10 & 1.44 \\
\hline 29 & GRMARSH & Outer border marshland area along coast of Groningen (m from dyke) & -7.70 & 0.48 \\
\hline 30 & PHYTWIN & $\begin{array}{l}\text { Annual winter (Dec, Jan, Feb, Mar) phytoplankton colour averaged } \\
\text { for North Sea }\end{array}$ & -0.22 & 0.71 \\
\hline 31 & CHLOR_A & Annual average chlorophyll a concentration in Marsdiep tidal inlet & 1.76 & -0.18 \\
\hline 32 & SPM & $\begin{array}{l}\text { Suspended particulate matter estimated from Secchi disk at high tide } \\
\text { in Marsdiep (Jul, Aug, Sep) }\end{array}$ & -1.07 & 0.27 \\
\hline 33 & PHAEOBLO & $\begin{array}{l}\text { Length of Phaeocystis spp. bloom periods (cells }>1000 \mathrm{~cm}^{-3} \text { ) in } \\
\text { Marsdiep }\end{array}$ & & 2.03 \\
\hline 34 & CALSUM & $\begin{array}{l}\text { Abundance of total Calanus spp. for North Sea, summer averages } \\
\text { (Jun, Jul, Aug, Sep) }\end{array}$ & 0.15 & -1.71 \\
\hline 35 & COPEP & $\begin{array}{l}\text { Abundance of total copepods for North Sea, summer averages } \\
\text { (Jun, Jul, Aug, Sep) }\end{array}$ & 0.12 & -0.30 \\
\hline 36 & CERMAC & $\begin{array}{l}\text { Frequency of occurrence of dinoflagellate Ceratium macroceros in } \\
\text { southern North Sea in continuous plankton recorder samples }\end{array}$ & -5.48 & 2.19 \\
\hline 37 & POLYCHAET & Late winter polychaete biomass in Balgzand, Wadden Sea & 2.80 & 1.66 \\
\hline 38 & BIVALVE & $\begin{array}{l}\text { Late winter bivalve biomass (mg AFDW m }{ }^{-2} \text { ) in Balgzand, } \\
\text { Wadden Sea }\end{array}$ & 1.74 & 0.24 \\
\hline
\end{tabular}


Table 1 (continued)

\begin{tabular}{|c|c|c|c|c|}
\hline $\begin{array}{l}\text { Var. } \\
\text { no. }\end{array}$ & Abbreviation & Description & $\begin{array}{l}979 \text { change } \\
\text { Mean of } \\
\text { Regimes I-II }\end{array}$ & $\begin{array}{c}1988 \text { change } \\
\text { Mean of } \\
\text { Regimes II-III }\end{array}$ \\
\hline 39 & BIO_CEREDU & $\begin{array}{l}\text { Biomass of cockle Cerastoderma edule flesh (billion kg) in } \\
\text { Wadden Sea }\end{array}$ & 0.10 & -0.39 \\
\hline 40 & CAT_CEREDU & $\begin{array}{l}\text { Catch of cockle Cerastoderma edule flesh (billion kg) in } \\
\text { Wadden Sea }\end{array}$ & 1.57 & 0.10 \\
\hline 41 & GASTRO & Late winter gastropod biomass in Balgzand, Wadden Sea & 1.36 & 0.03 \\
\hline 42 & CRACRA & $\begin{array}{l}\text { Mean }>54 \mathrm{~mm} \text { year class abundance of brown shrimp Crangon } \\
\text { crangon on the west coast of Schleswig-Holstein, Germany }\end{array}$ & 0.33 & -1.92 \\
\hline 43 & LANDCOD & International landing of cod from ICES Quadrants III, IV, VIId & -0.27 & -5.50 \\
\hline 44 & sqrtLANDHER & International landing of herring from ICES Quadrants III, IV, VIId & 0.60 & 1.23 \\
\hline 45 & LANDHAD & International landing of haddock from ICES Quadrants III, IV, VIId & -1.94 & -2.42 \\
\hline 46 & LANDWHIT & International landing of whiting from ICES Quadrants III, IV, VIId & -2.53 & -1.87 \\
\hline 47 & LANDSOLE & International landing of sole from ICES Quadrants III, IV, VIId & 0.02 & 1.14 \\
\hline 48 & LANDPLAI & International landing of plaice from ICES Quadrants III, IV, VIId & 4.02 & -1.75 \\
\hline 49 & HORSE & Catches of horse mackerel (1000 t) from NE Atlantic & -1.28 & 6.53 \\
\hline 50 & NOR_POU & $\begin{array}{l}\text { International bottom trawl survey in North Sea: Norway pout } \\
\text { recruitment yield (avg. no. } \mathrm{h}^{-1} \text { fishing) }\end{array}$ & & 0.03 \\
\hline 51 & SPRAT & $\begin{array}{l}\text { International Bottom Trawl Survey in North Sea: sprat recruitment } \\
\text { yield (avg. no. } \mathrm{h}^{-1} \text { fishing) }\end{array}$ & & 0.90 \\
\hline 52 & COD & $\begin{array}{l}\text { International Bottom Trawl Survey in North Sea: cod recruitment } \\
\text { yield (avg. no. } \mathrm{h}^{-1} \text { fishing) }\end{array}$ & & 0.07 \\
\hline 53 & WHIT & $\begin{array}{l}\text { International Bottom Trawl Survey in North Sea: whiting recruitment } \\
\text { yield (mean no. } \mathrm{h}^{-1} \text { fishing) }\end{array}$ & & 1.29 \\
\hline 54 & OSMEPE & Relative abundance of smelt Osmerus eperlanus in NCP & & -0.34 \\
\hline 55 & LIMLIM & Relative abundance of dab Limanda limanda in NCP & & 1.12 \\
\hline 56 & LIPLIP & Relative abundance of sea-snail Liparis liparis in NCP & & -2.20 \\
\hline 57 & CLUHAR & $\begin{array}{l}\text { Relative abundance of herring Clupea harengus in North Sea } \\
\text { (including Skagerrak/Kattegat) }\end{array}$ & & 1.86 \\
\hline 58 & GADMOH & $\begin{array}{l}\text { Relative abundance of cod Gadus morhua in North Sea } \\
\text { (including Skagerrak/Kattegat) }\end{array}$ & & 0.31 \\
\hline 59 & SOLVUL & $\begin{array}{l}\text { Relative abundance of sole Solea vulgaris in North Sea } \\
\text { (including Skagerrak/Kattegat) }\end{array}$ & & -1.41 \\
\hline 60 & BUGLUT & Relative abundance of solenet Buglossidium luteum in NCP & & 3.22 \\
\hline 61 & ARNLAT & Nos. ha ${ }^{-1}$ of scald fish Arnoglossus laterna in NCP & 0.13 & 2.72 \\
\hline 62 & ECHVIP & Nos. ha ${ }^{-1}$ of lesser weever Echiichthys vipera in NCP & 0.60 & 2.52 \\
\hline 63 & PLEPLA & $\begin{array}{l}\text { Recruit numbers } \mathrm{d}^{-1} \text { of plaice Pleuronectes platessa in Marsdiep, } \\
\text { Wadden Sea }\end{array}$ & 2.51 & -1.01 \\
\hline 64 & CLUPHA & $\begin{array}{l}\text { Recruit numbers d }{ }^{-1} \text { of herring Clupea harengus in Marsdiep, } \\
\text { Wadden Sea }\end{array}$ & 4.89 & 0.98 \\
\hline 65 & ALOFAL & $\begin{array}{l}\text { Recruit numbers d }{ }^{-1} \text { of twait chad Alosa fallax in Marsdiep, } \\
\text { Wadden Sea }\end{array}$ & 0.49 & 0.80 \\
\hline 66 & POLPOL & $\begin{array}{l}\text { Recruit numbers d }{ }^{-1} \text { of pollack Pollachius pollachius in Marsdiep, } \\
\text { Wadden Sea }\end{array}$ & 0.15 & -0.72 \\
\hline 67 & MERMER & $\begin{array}{l}\text { Recruit numbers d }{ }^{-1} \text { of whiting Merlangius merlangus in Marsdiep, } \\
\text { Wadden Sea }\end{array}$ & 1.22 & -0.50 \\
\hline 68 & OYSTERC & $\begin{array}{l}\text { Total calculated bird days in January for oystercatcher (in Dutch } \\
\text { Wadden Sea) }\end{array}$ & 0.46 & 0.35 \\
\hline 69 & WORM.EAT & $\begin{array}{l}\text { Total calculated bird days in January for worm-eating wader species } \\
\text { in Dutch Wadden Sea }\end{array}$ & -4.12 & 1.14 \\
\hline 70 & BRABRA & $\begin{array}{l}\text { Number of dark-bellied Brent geese Branta branta bernicla in western } \\
\text { Europe based on sightings and from } 2000 \text { to } 2002 \text { on estimation }\end{array}$ & m 4.04 & 2.87 \\
\hline 71 & BRA_CHICK & $\begin{array}{l}\text { Percentage of first year dark-bellied Brent geese chicks in western } \\
\text { Europe }\end{array}$ & -0.38 & 0.23 \\
\hline 72 & FLEDGE & Number of eider duck fledglings on Dutch island of Vlieland & 2.47 & \\
\hline 73 & SEAL & Stranding of total seal species on beaches of southern North Sea & 1.95 & 0.01 \\
\hline 74 & SEALPUPS & $\begin{array}{l}\text { Percentage counted pups in total number of sightings of harbour } \\
\text { seal Phoca vitulina in Wadden Sea }\end{array}$ & 0.35 & 3.48 \\
\hline 75 & PHOVIT & $\begin{array}{l}\text { Population count of the harbour seal Phoca vitulina in the Dutch } \\
\text { Wadden Sea }\end{array}$ & 0.60 & 1.52 \\
\hline 76 & PHOPHO & $\begin{array}{l}\text { Sightings of porpoises Phocoena phocoena along Dutch and } \\
\text { Belgium North Sea coastlines (corrected } \mathrm{h}^{-1} \text { ) }\end{array}$ & 14.10 & 4.85 \\
\hline
\end{tabular}


secutive years around each putative shift (1978 or 1979, 1988 or 1989, 1997 or 1998) resulting in a stepmagnitude of the expected year of the shift (based on the literature) and the 2 years before and after each year. This gave us an objective method of identifying the years with the highest step-magnitude. The regime shift analysis technique is described in detail in Ebbesmeyer et al. (1991) and Hare \& Mantua (2000); the basic procedure is:

Step 1. For each time series, calculate the mean (of the entire time series) and the standard deviation of Regimes 1 and 2.

Step 2. Normalise each time series by subtracting the mean value and dividing by the appropriate standard deviation. The underlying idea of using 2 different standard deviations is that a sudden change in the system might result in an increase in variation. However, in this analysis we are only interested in the absolute value of the shift, and not in an increase of variance.

Step 3. Because we are not interested in the sign of the step, some series are reversed such that the step has the same sign in all time series. A series was reversed $\left(Y_{t}=-1 \times Y_{t}\right.$ for all years $\left.t\right)$ if the mean value in the first regime was higher than in the second regime. Therefore, we will always find an increasing step.

Step 4. Calculate the average value for each year using all the (modified) time series.

Step 5. Calculate the standard error for each year using $s / n^{0.5}$, where $n$ is the number of time series in a year and $s$ the standard deviation in that year.

Step 6. Calculate regime averages using the mean values (obtained in Step 3). The overall step-magnitude can be defined as the difference between these 2 mean values.

To visualise the change, a smoother can be fitted or the regime averages can be plotted as horizontal lines. To assess whether the change in the regime averages is an artifact of the algorithm or not, (1) the width of the standard errors can be inspected, and (2) one can examine the change in the regime averages for different values of the time of shift (e.g. compare results using a sliding window).

The statistical software package Brodgar (available at: www.brodgar.com) contains an implementation of this algorithm, and was used here. To apply RSA the data were grouped into regimes prior to and after the suspected shift, with each regime being of equal number of years - $10 \mathrm{yr}$ in the case of the suspected 1979 and 1988 shifts, and 4 to $6 \mathrm{yr}$ in the case of the 1998 shift. Following the approach of Ebbesmeyer et al. (1991), we only included time series for which there were at least 5 data points per regime. Besides the difference between the mean values of the 2 regimes (see Step 6 of the RSA algorithm above), it is also interest- ing to examine the differences in the mean values of the individual time series between the 2 regimes. These are obtained in Step 3 and shown in Table 1.

The use of RSA and its combination with PCA has recently been criticized by Rudnick \& Davis (2003). Using randomly generated time series (red noise) they found regime shifts with the methodology described above. In a follow-up paper, Hare \& Mantua (in press) defended their approach. Because of this, we decided to apply another statistical technique, capable of detecting breakpoints in multivariate time series, namely chronological clustering. This technique is described in Legendre et al. (1985), Bell \& Legendre (1987) and Legendre \& Legendre (1998). The first 2 studies can be downloaded from www.fas.umontreal. ca/biol/legendre/reprints/.

The disadvantage of clustering techniques applied to time series data is that they end up in groups of nonsequential years, which makes the interpretation difficult. Chronological clustering results in groups of sequential years, and therefore allows the identification of breakpoints. At this point, it is interesting to mention that chronological clustering applied to the North Pacific time series data analysed in Hare \& Mantua (2000) identifies the same regime shifts, namely in 1977 and 1989 (see the Brodgar manual: www.brodgar.com).

Before this technique can be applied, the measure of association between years, the significance level alpha and the connectedness has to be determined. Alpha can be considered as a clustering-intensity parameter. Small values of alpha (0.01 to 0.1$)$ show the most important breakpoints in the time series, whereas larger values (0.1 to 0.3 ) show small-scale variation. Legendre et al. (1985) argued that using the same connectedness level (e.g. 50\%) and different values for alpha is the most informative, and this approach was followed here. Legendre et al. (1985), and Legendre \& Legendre (1998) used zoobenthic data, for which the Whittaker index of association is a sensible choice to define similarity between years. For our data, this is not appropriate because some of the variables take negative values. Therefore, we first standardised each variable, and then used the Euclidean distance function to calculate the (dis)similarity between years. The software package Brodgar was used for these calculations.

\section{RESULTS}

\section{Principal component analysis}

The eigenvalues from PC1 to PC10 of PCA using the environmental and biological time series com- 
bined show that the first 3 PCs explained $43 \%$ of the variance. PC1, with an eigenvalue of $21.1 \%$, can be interpreted as a pattern with an abrupt change in 1987-1988, where values switch from positive to negative or as a pattern with 3 regimes: positive until 1979, then a gradual decline until 1988, after which it was strongly negative (Fig. 2). Almost half of the variables $(47 \%)$ were strongly related to PC1, as they had loadings $>|0.5|$, and as much as $71 \%$ had loadings of $>|0.3|$. These variables were evenly distributed over the food chain, with highest loadings found for a number of variables relating to fish species (positive loadings for the landing of cod, haddock and whiting and negative for the abundance of lesser weever, solenet, scaldfish). High negative loadings were also found for the abundance of polychaetes, for the number of strandings of seals in the southern North Sea, and for the number of Brent geese chicks in western Europe. The environmental variable with the strongest positive relation with the first PC was salinity in the North Sea, and the variables most strongly negatively related were temperature indices (surface temperature in De Kooy, average surface temperature over central England, and sea-surface temperature of the North Sea).

PC2, eigenvalue $12 \%$, showed 2 abrupt changes dividing the PC into 3 clear regimes: negative until 1979, then a switch to strongly positive until 1989, after which it flipped back and forth (Fig. 2). This PC had high values before 1988, after which the scores became rather small. Of the variables, $52 \%$ had a relationship with PC2; of these, $23 \%$ had a loading $>|0.5|$. Ecological variables with the highest positive loading were chlorophyll a concentration in the Wadden Sea, and the number of plaice and herring recruits in the Marsdiep (an inlet in the western Wadden Sea). Variables with the highest negative loading were the frequency of occurrence of the dinoflagellate species Ceratium macroceros, the catches of horse mackerel in the NE Atlantic, and the abundance of worm-eating wader birds. The physical variable with the strongest positive association with PC2 was the solar constant, and the strongest inverse relationships were with North Sea winter sea-surface temperature and Wadden Sea salinity.

PC3, with an eigenvalue of $10 \%$, was the first to show an abrupt change in 1998, but showed no shift in 1978 or 1979 and in the late 1980s became only briefly negative (Fig. 2). Of the 73 variables, 33 had a strong association with Axis 3, i.e. loadings $>|0.3|, 17$ with a loading higher than $|0.5|$. The biomass of cockles in the Wadden Sea and the summer abundance of copepods Calanus spp. were inversely related to $\mathrm{PC} 3$; the abundance of herring in the North Sea and the winter phytoplankton abundance were positively related. Among environmental variables, mean high tide in the Wadden Sea and wind direction in De Kooy (a station in North Holland, close to the
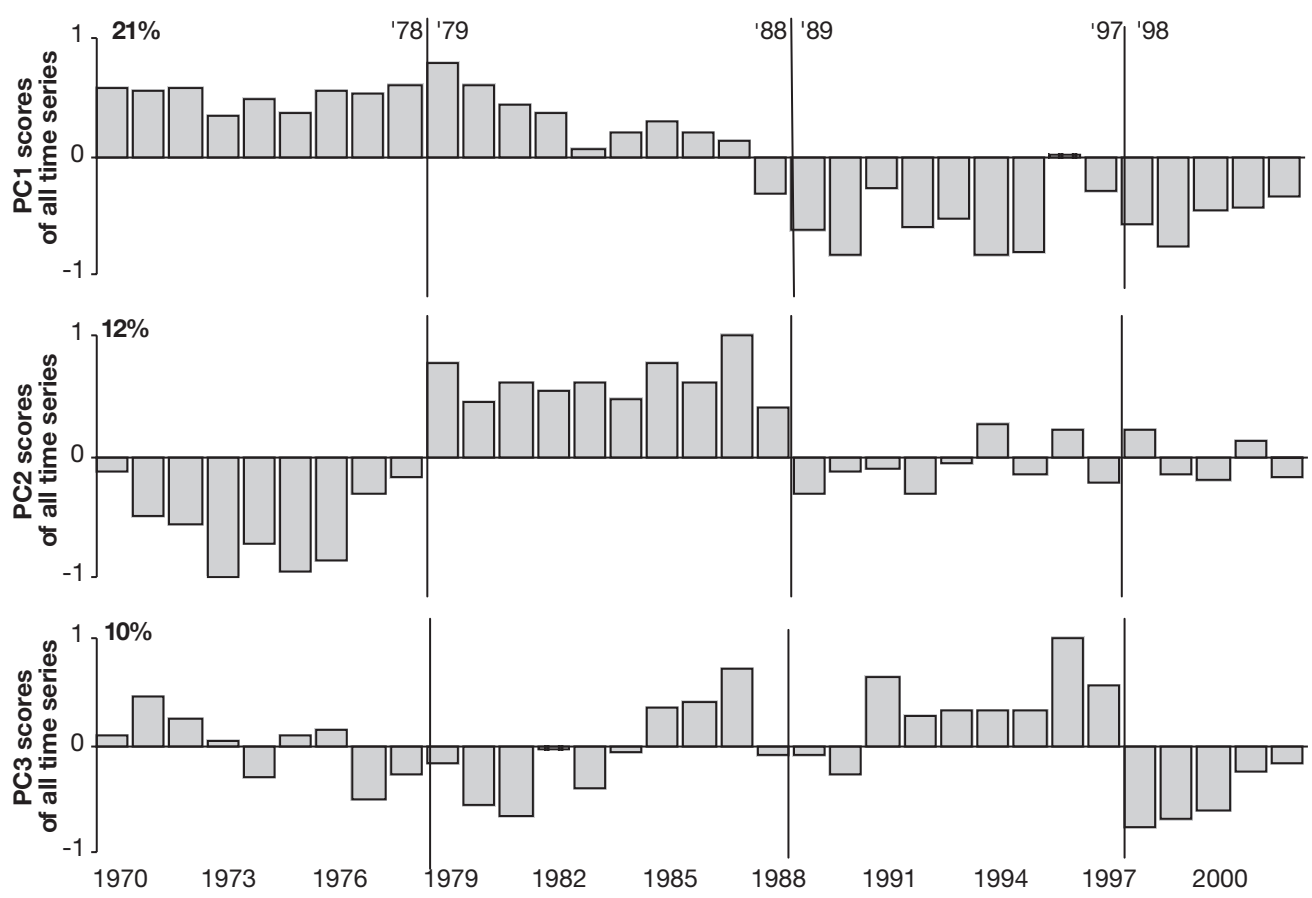

Fig. 2. Principal component (PC) scores of principal component analysis (PCA) of environmental and biological time series combined from 1970 to 2002. Eigenvalue given as percentage in top left-hand corner for each score series 

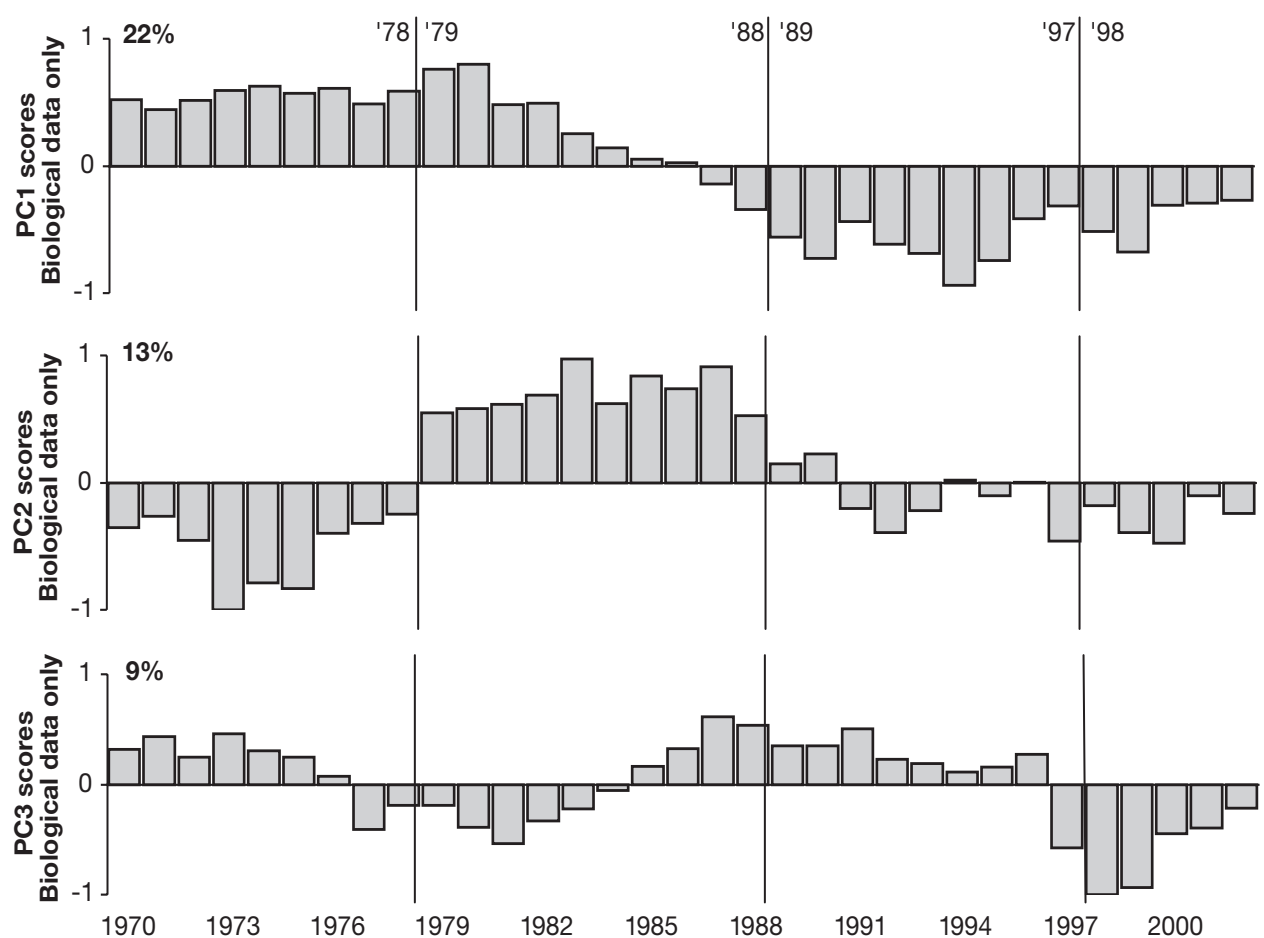

Fig. 3. Principal component (PC) scores of PCA of 46 biological time series from 1970 to 2002. Eigenvalue given as percentage in top left-hand corner for each score series

coast) had the strongest negative relationship with PC3, and surface air pressure the strongest positive relationship.

In summary, PC1 appeared to show the proposed 1987 or 1988 shift in the North Sea and Wadden Sea most strongly. PC2 indicated abrupt changes in 1979 and 1989, and a possible third shift in 1998 might be indicated by PC3.

\section{Biological time series}

The PC scores of the PCA of biological variables only (Fig. 3) showed a large similarity with those of the PCA of the combined data sets (Fig. 2). Eigenvalues were similar too so again we used the first $3 \mathrm{PCs}$, which explained $44 \%$ of the variance. Note that the biological-only PCs were noticeably smoother (more gradual year-to-year change) than combined PCs. Only PC2 showed an abrupt change in 1979.

Regime shifts in 1979 and 1988 were clearly present in PC2, but the possible regime shift in 1998 was not obvious in any of the 3 PCs. Variables with high loadings were similar to those of the combined environmental and biological data sets. The ordination diagram in Fig. 4 showed 3 distinct regimes: 1970 to 1978 in one cluster, 1979 to 1988 in another, and 1989 to 2002 in a third cluster.

\section{Environmental time series}

PC1 and PC2 explained $48.7 \%$ of the variation. Fig. 5 shows a shift in 1987 from a predominant positive phase to a negative phase in the first PC (eigenvalue $28 \%$ ). The second PC (eigenvalue 17\%) alternated between positive and negative, with changes coinciding with the proposed 1979, 1988 and 1998 shifts (Fig. 5). As the pattern of this axis was predominantly related to local climate indices (surface air pressure, cloud cover and amount of precipitation in De Kooy: loadings $>|0.80|$ ), we also included a third axis. The third PC scores showed an abrupt change in 1979, changing from positive to negative (although in 1980 and 1981 briefly flipping back to positive), and then in 1989 returning to the pre-1979 state for a few years. In conclusion, climate indices alone appeared to show abrupt changes in 1979 and 1988, but these seemed to be less strong than those of the biological variables.

Out of 25 physical variables, 15 had a loading $>|0.50|$, indicating a strong relationship with the pattern of the first PC. The parameters that had the strongest relationship (loadings $>|0.80|$ ) were surface air temperature in De Kooy, winter temperature in the Wadden Sea, sea-surface temperature in the North Sea, the NAO winter index, and mean high tide in the Wadden Sea (all negative loadings). The number of days with frost was the only variable with a large posi- 


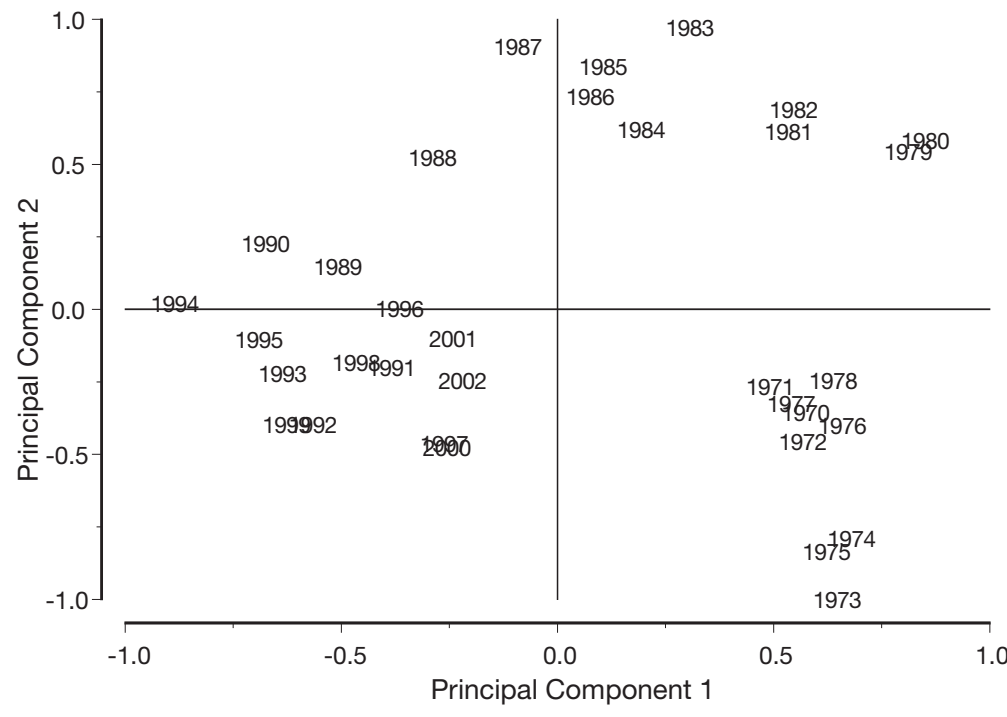

Fig. 4. Clusters of samples in PCA ordination diagram of 46 biological standardised time series from 1970 to 2002

tive loading. As only weather variables (surface air pressure, cloud cover and precipitation) from 1 station were highly related to the second axis, it was very likely related to conditions on a more local scale. Salinity in the North Sea and sunspot number were positively related to $\mathrm{PC} 3$, as was the winter sea-surface temperature of the North Sea. Variables with high negative loadings were average surface temperature in central England and the winter N:P ratio in the North Sea.

The ordination diagram of environmental variables alone (Fig. 6) did not show the 3 clusters evident in the biological-only biplot (Fig. 4).

\section{Regime shift analyses}

As PCA results appeared to corroborate the possible shifts of 1978 or 1979,1988 or 1989 , and (less clearly) 1998 or 1999, we based the regime shift analysis around those years. Using a sliding window approach, we determined the exact end-point of the regime shift (bold in Table 2) represented by the largest calculated stepmagnitude between 2 regimes (Step 6 of the RSA algorithm in 'Material and methods'). Results are shown in Table 2.

In agreement with our assessment of the PCA results, the first step was largest in 1979, the second in 1988, and the third in 1998. Table 1 shows the step-magnitudes for each individual time series in both 1979 and 1988 (i.e. the change between the regime before and after years 1979 and 1988). As we only had a limited number of data points for the 1998 shift, we shall not go into more detail for that shift. In both 1979 and 1988 there was an upwards step (in both cases more negative values in the pre-shift compared
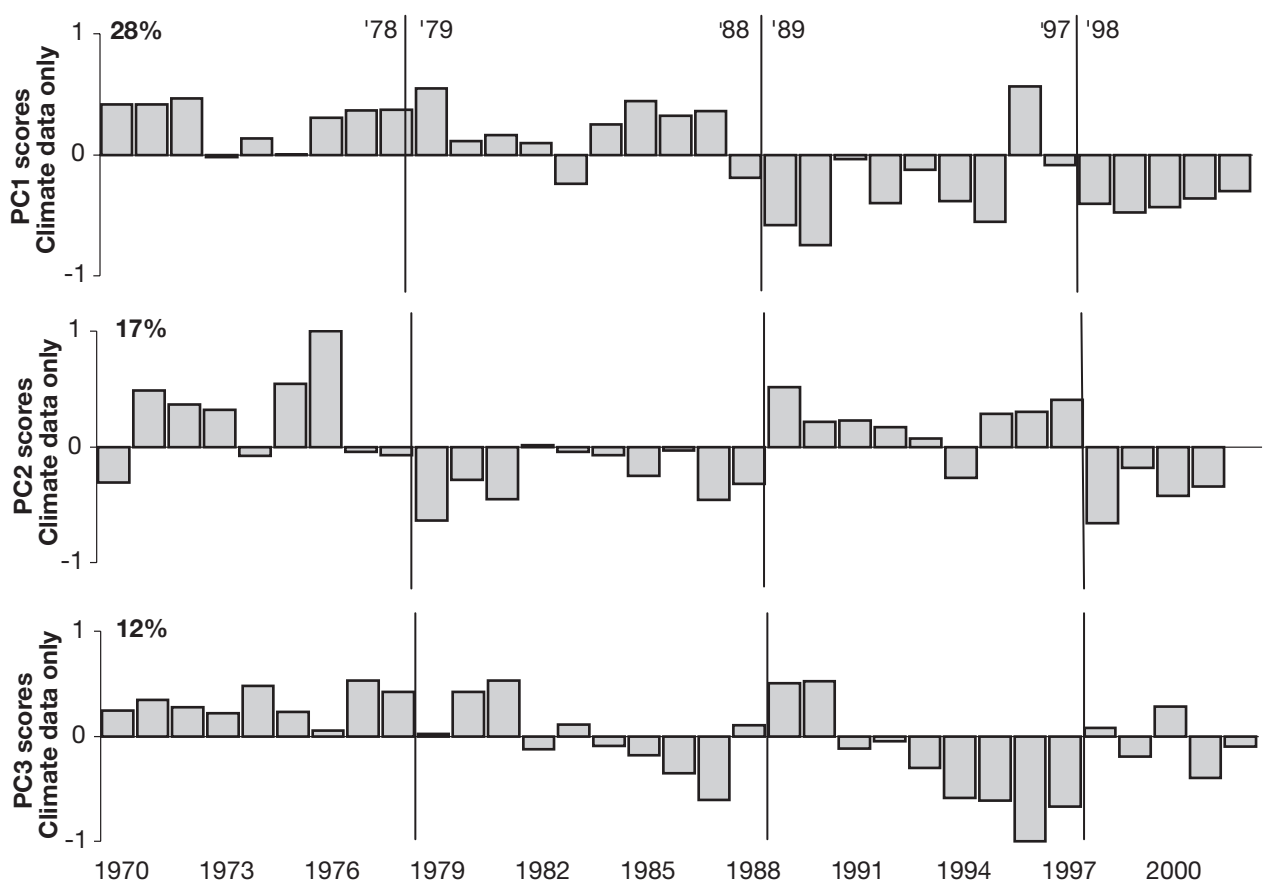

Fig. 5. Principal component (PC) scores of PCA of 25 climate time series from 1970 to 2002. Eigenvalue given as percentages in top left-hand corner for each score series 


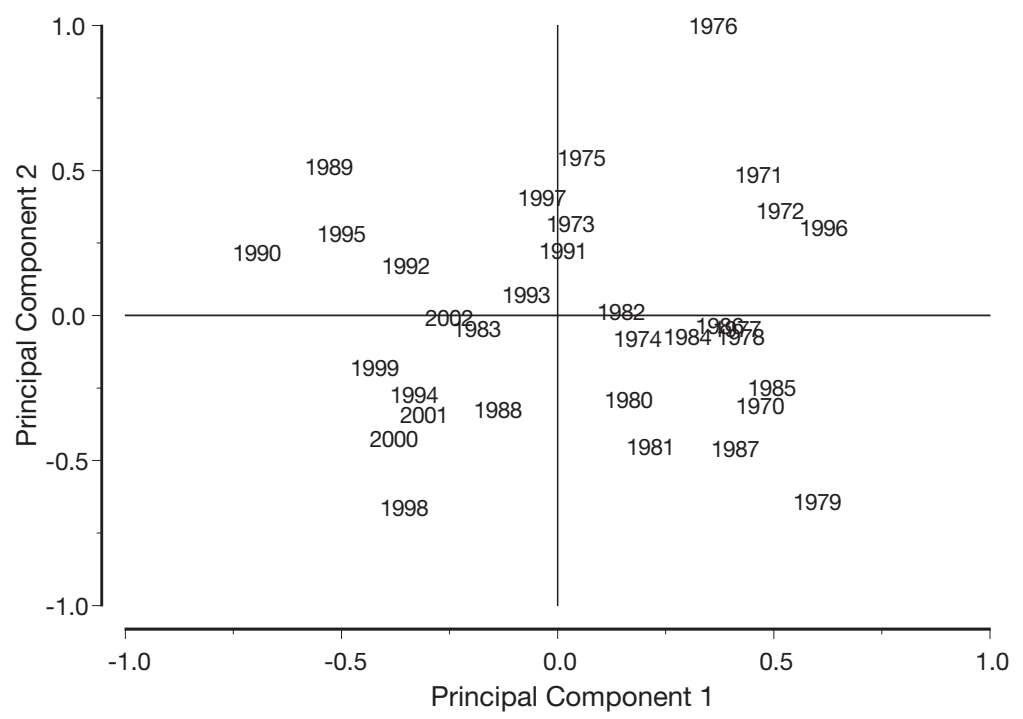

Fig. 6. PCA ordination diagram of 25 environmental standardised time series from 1970 to 2002 variable nos. as in Table 1), to step-magnitude in 1979 and 1988. As can be seen, the contribution of individual variables to the shift size is fairly diverse.

The 5 climate and 10 biological variables displaying the largest difference between 2 regimes (largest step magnitude) are summarized in Table 4.

In the 1979 regime shift, the solar constant, the East Atlantic teleconnection pattern and the mean high tide in the Wadden Sea all suddenly increased, whereas salinity in both the North Sea and the Wadden Sea suddenly decreased. The number of porpoise sightings in the North Sea greatly increased between before and after 1979, followed by area of marshland, the abundance of a dinoflagellates species (Ceratium macroceros), some fish species, worm-eating wader birds, and the dark- to the post-shift regime, Table 1). This indicates a general upwards trend which corresponds with the main underlying pattern of PC1 (Fig. 2).

Step-magnitudes of 1979 and 1988 are presented in Fig. 7. Additionally we added a smoothing curve (obtained by additive modelling; Hastie \& Tibshirani 1990) to aid visual interpretation. Note that the SE bars before and after the shift in Fig. 7 do not overlap.

Table 3 shows the results of the stepmagnitudes for the biological and climate time series separately. The largest shift size in the climate data was 1 yr before the largest shift size in the biological time series. This was true for both the first and the second step. In addition, both steps were more prominent (of larger magnitude) in biological variables only compared with environmental variables only (see also Fig. 8, results shown for 1988 shift).

Fig. 9 shows the contribution of the variables, i.e. individual time series (description of abbreviations and
Table 3. Regime shift analysis using sliding window approach to calculate the step magnitudes of biological-only and environmental-only time series by averaging the annual means of $10 \mathrm{yr}$ before and $10 \mathrm{yr}$ after the year of suspected regime shift. No. of standardised time series used for calculation are given in parentheses. Bold indicates end-point of regime shifts

\begin{tabular}{|cccc|}
\hline \multicolumn{2}{|c|}{$\begin{array}{c}\text { Biological variables only } \\
\text { Magnitude }\end{array}$} & \multicolumn{2}{c|}{$\begin{array}{c}\text { Environmental variables only } \\
\text { Magnitude }\end{array}$} \\
\hline Step I & & & \\
1976 & $1.49(22)$ & 1976 & $0.85(24)$ \\
1977 & $1.59(28)$ & 1977 & $0.90(25)$ \\
1978 & $1.70(29)$ & $\mathbf{1 9 7 8}$ & $\mathbf{0 . 9 3}(25)$ \\
$\mathbf{1 9 7 9}$ & $\mathbf{1 . 9 0}(37)$ & 1979 & $0.79(25)$ \\
1980 & $1.67(38)$ & 1980 & $0.71(25)$ \\
1981 & $162(38)$ & 1981 & $0.68(25)$ \\
Step II & & & \\
1986 & $1.37(48)$ & 1986 & $0.79(27)$ \\
1987 & $1.37(48)$ & $\mathbf{1 9 8 7}$ & $\mathbf{0 . 9 2}(27)$ \\
$\mathbf{1 9 8 8}$ & $\mathbf{1 . 4 4}(48)$ & 1988 & $0.91(27)$ \\
1989 & $1.43(47)$ & 1989 & $0.82(27)$ \\
1990 & $1.29(45)$ & 1990 & $0.68(27)$ \\
\hline
\end{tabular}

Table 2. Sliding window approach for calculating step magnitudes by averaging annual means of 10 yr before and 10 yr after year of suspected regime shift. For late 1990s only a limited number of years were available to calculate average step magnitude (no. of years given in parentheses). No. of standardised time series used for calculation includes environmental and biological time series out of total of 75 ( 25 environmental and 50 biological). Bold indicates end-points of regime shifts

\begin{tabular}{|c|c|c|c|c|c|c|c|c|}
\hline Step I & Magnitude & $\begin{array}{c}\text { No. of } \\
\text { time series }\end{array}$ & Step II & Magnitude & $\begin{array}{c}\text { No. of } \\
\text { time series }\end{array}$ & Step III & Magnitude & $\begin{array}{c}\text { No. of } \\
\text { time series }\end{array}$ \\
\hline 1976 & 1.08 & 46 & 1986 & 1.16 & 75 & 1996 & 1.10 & 52 (6 yr) \\
\hline 1977 & 1.20 & 53 & 1987 & 1.21 & 75 & 1997 & 1.39 & 45 (5 yr) \\
\hline 1978 & 1.33 & 54 & 1988 & 1.25 & 75 & 1998 & 1.61 & 45 (4 yr) \\
\hline 1979 & 1.42 & 62 & 1989 & 1.21 & 74 & & & \\
\hline 1980 & 1.26 & 63 & 1990 & 1.03 & 71 & & & \\
\hline 1981 & 1.16 & 62 & 1991 & 1.00 & 70 & & & \\
\hline
\end{tabular}



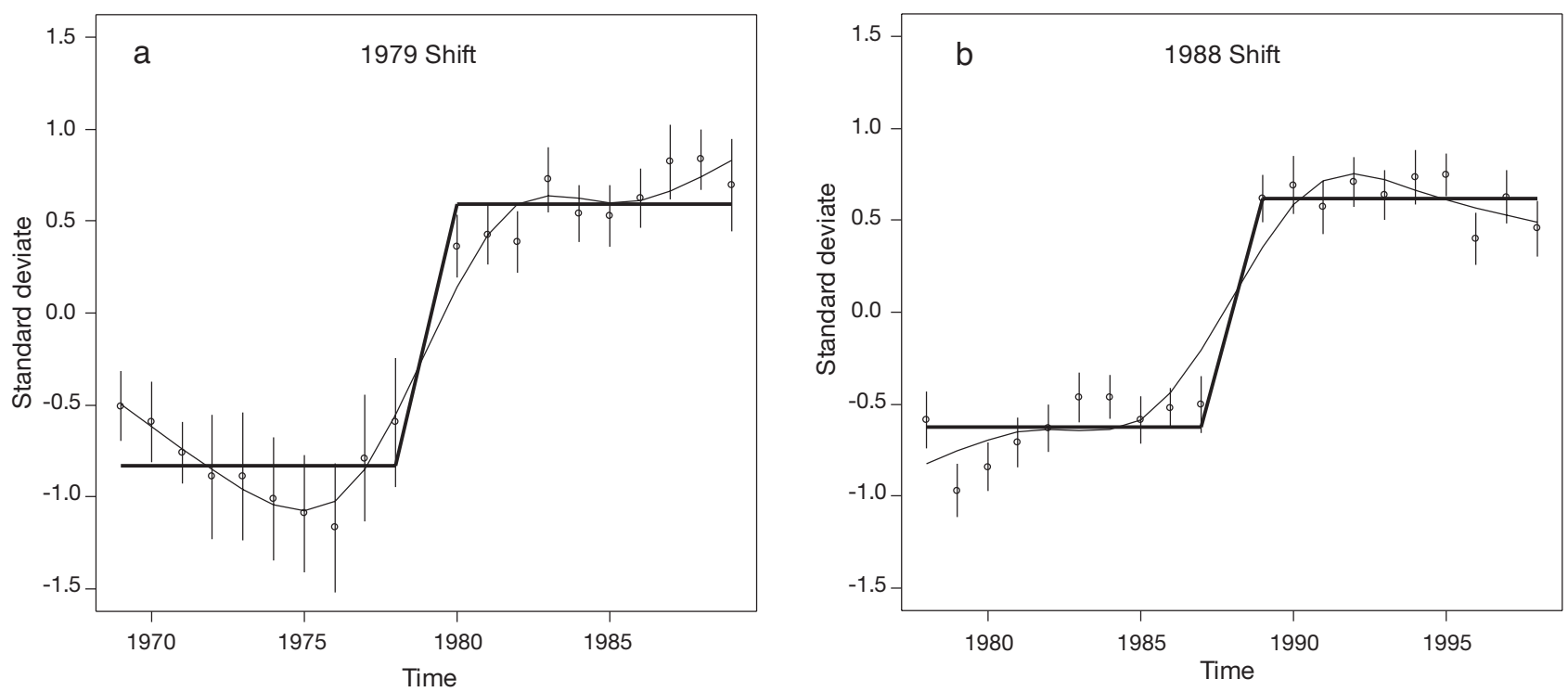

Fig. 7. Results of step analyses showing 2 consecutive upward steps in (a) 1979 and (b) 1988. Circles represent annual means of standardised time series, and the bars represent \pm 2 SE. Continuous line is a generalized additive model (GAM) with $6 \mathrm{df}$
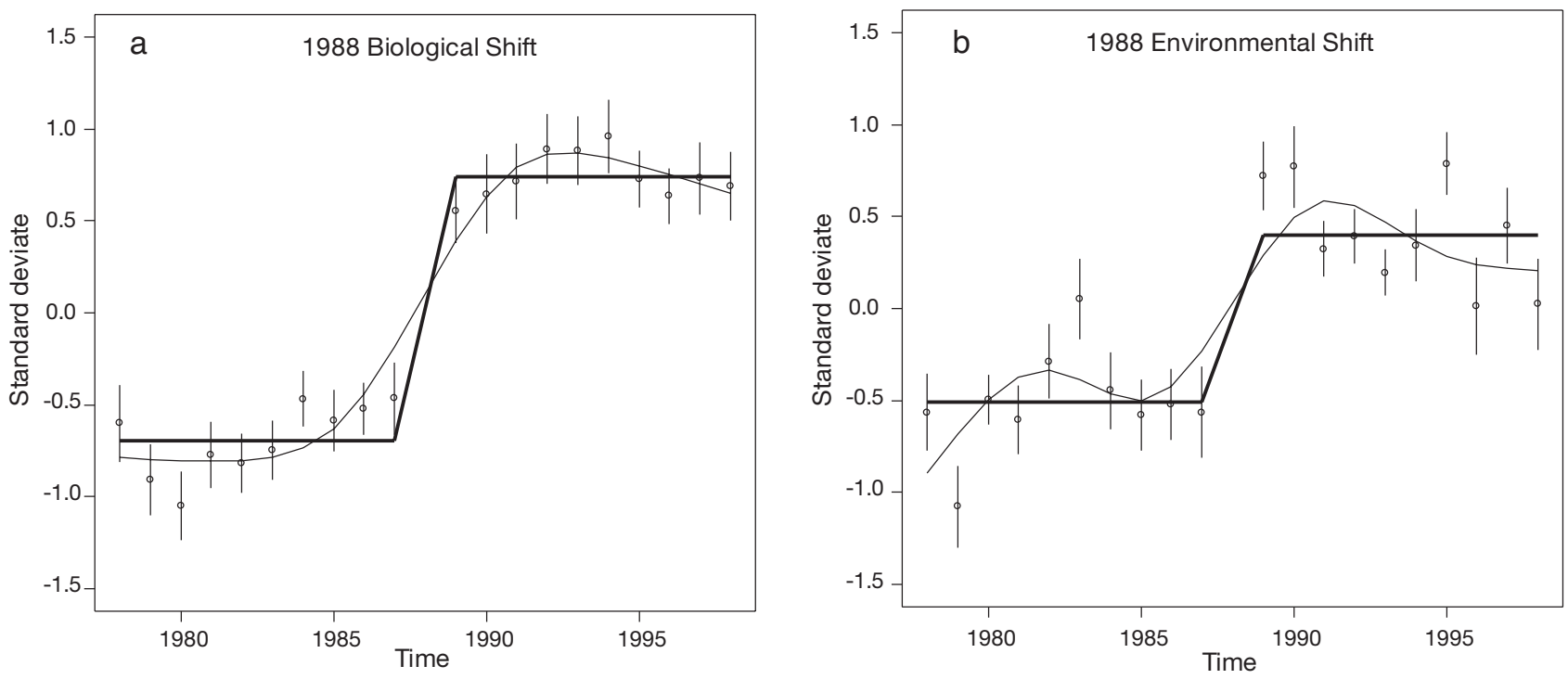

Fig. 8. Results of 1988 regime shift analyses for (a) biological and (b) environmental variables. Circles represent annual means of standardised time series, and the bars represent \pm 2 SE. Continuous line is a generalized additive model (GAM) with $6 \mathrm{df}$

bellied Brent geese, and to a lesser extent the biomass of polychaetes and the landing of whiting. The 1988 regime shift seems to be triggered by climate variables as only temperature indices showed a sudden jump. Among the biological variables, increased abundance of several fish taxa coincided with the 1988 regime shift.

\section{Chronological clustering}

\section{Combined data}

The results for the combined biological and environmental data are presented in Fig. 10. They can be interpreted as follows: 5 lines correspond to different 

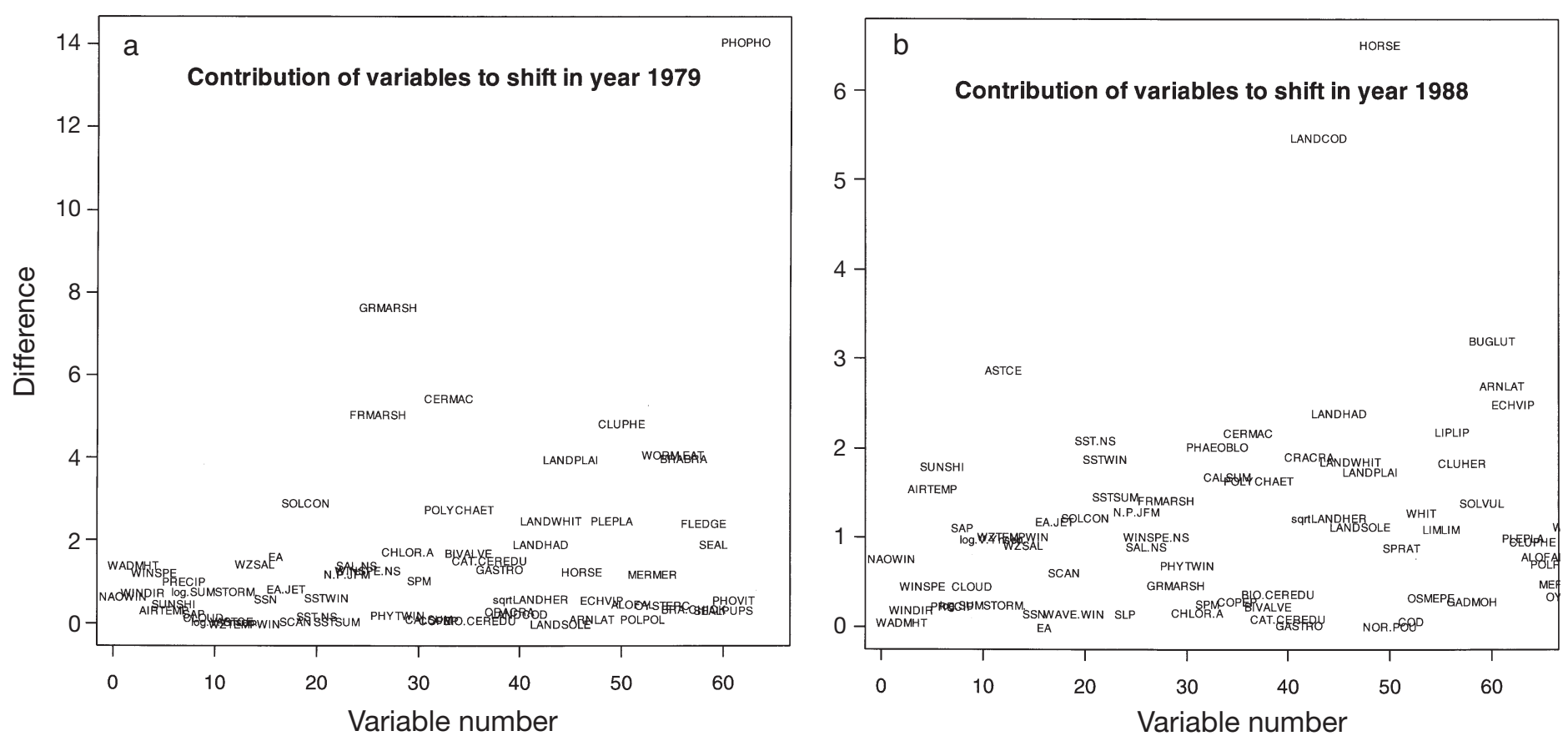

Fig. 9. Contribution of individual standardised time series to average absolute step magnitude in (a) 1979 and (b) 1988. See Table 1 for description of abbreviations and variable no.

values of alpha, the clustering intensity parameter. The line with alpha $=0.01$ provides a general overview and shows the most important breakpoints. The numbers on each line correspond to groups of years, and a vertical line represents the start of a new group. Hence, for the combined data, there were major breakpoints in 1979 (or 1978) and 1988 (or 1987). For larger values of alpha, the same breakpoints were obtained, but there was clearly more variation in the 1980s. An a priori test (Legendre et al. 1985) showed that years in
Group 1 were not only different from Group 2, but also from Group 3. Hence, chronological clustering revealed 3 different regimes in the combined biological and environmental variables.

\section{Biological data}

The results of chronological clustering applied to the biological data are presented in Fig. 11. The years 1979

Table 4. Time series with the largest differences between 2 consecutive regimes. Difference in 1979 is between 1969 to 1978 (Regime I) and 1980 to 1989 (Regime II), 1988 difference is between 1978 to 1987 (Regime II) and 1989 to 1998 (Regime III)

\begin{tabular}{|c|c|c|c|}
\hline Variables with largest difference in 1979 & $\begin{array}{l}\text { Shift } \\
\text { I-II }\end{array}$ & Variables with largest difference in 1988 & $\begin{array}{c}\text { Shift } \\
\text { II-III }\end{array}$ \\
\hline Solar constant & 2.94 & Average surface air temperature over central England & 2.88 \\
\hline Teleconnection pattern in East Atlantic & 1.65 & Sea-surface temperature in North Sea & 2.11 \\
\hline Salinity in Wadden Sea & -1.47 & Winter sea-surface temperature in North Sea & 1.89 \\
\hline Mean high tide in Wadden Sea & 1.44 & No. of sunshine hours & 1.81 \\
\hline Salinity in North Sea & -1.43 & Average air temperature at De Kooy & 1.56 \\
\hline Porpoise sightings in southern North Sea & 14.10 & Catches of horse mackerel for NE Atlantic & 6.53 \\
\hline Marshland area in Groningen & -7.70 & Landing of cod from North Sea catches & -5.50 \\
\hline Abundance of dinoflagellate in southern NS & -5.48 & Porpoise sightings in southern North Sea & 4.85 \\
\hline Marshland area in Friesland & 5.10 & No. of harbour seal pups in Wadden Sea & 3.48 \\
\hline Recruit number of herring in Marsdiep & 4.89 & Relative abundance of solenet in NCP & 3.22 \\
\hline Abundance of worm-eating waders & -4.12 & No. of dark-bellied Brent geese in Western Europe & 2.87 \\
\hline No. of dark-bellied Brent geese in western Europe & 4.04 & No. $\mathrm{ha}^{-1}$ of scaldfish in NCP & 2.72 \\
\hline Landing of plaice from North Sea catches & 4.02 & No. ha ${ }^{-1}$ of lesser weever in NCP & 2.52 \\
\hline Winter polychaete biomass & 2.80 & Landing of haddock from North Sea catches & -2.42 \\
\hline Landing of whiting from North Sea catches & -2.53 & Abundance dinoflagellate in southern North Sea & 2.19 \\
\hline
\end{tabular}




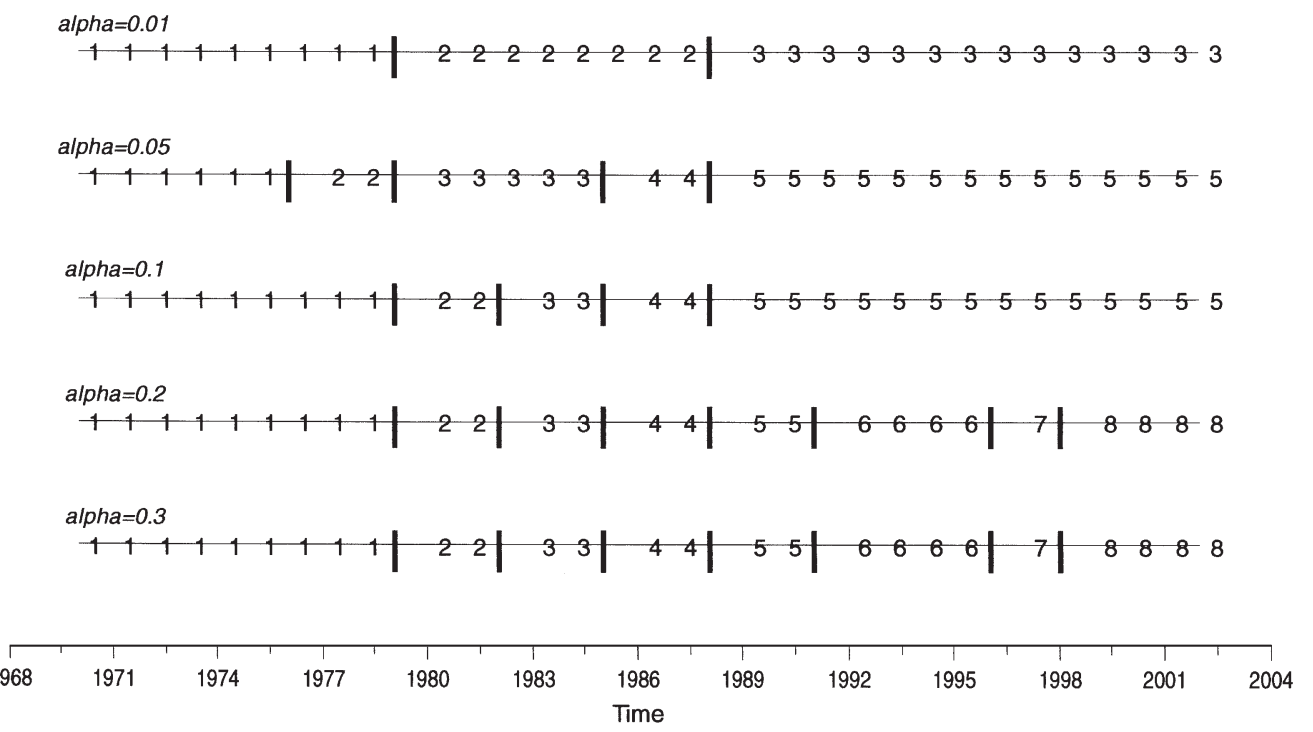

Fig. 10. Results of chronological clustering for the combined biological and environmental variables. Small values of alpha show the most important breakpoints (indicated by vertical lines). Numbers correspond to groups of years

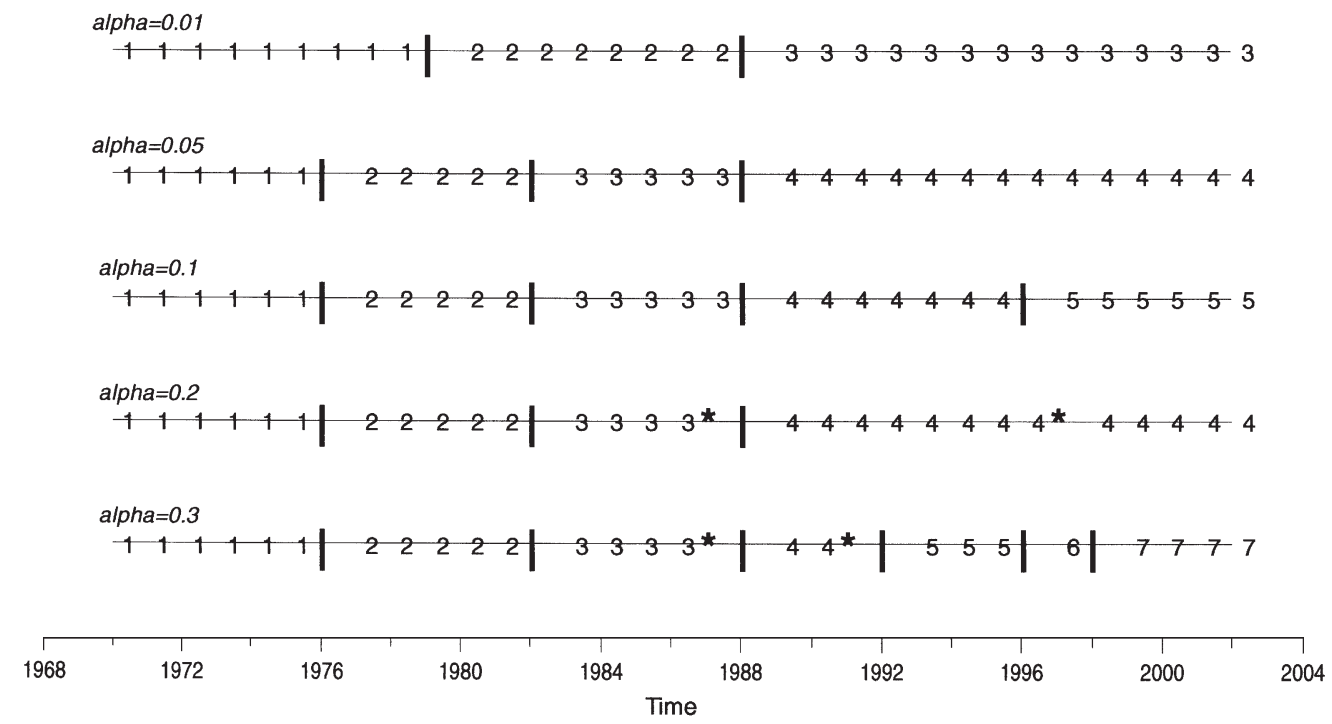

Fig. 11. Results of chronological clustering applied to the biological variables. Small values of alpha show the most important breakpoints (indicated by vertical lines). Numbers correspond to groups of years. *: 'singletons', years that do not belong to the group immediately before or after them and were thus omitted from the calculations

and 1988 were identified as the most important breakpoints. Note that for larger alpha values, 1988 was still identified as a breakpoint, but not 1979. This means that overall, 1979 was a major breakpoint but, when considered on a smaller scale, the years around 1979 differed also.

The asterisks in Fig. 11 are so-called 'singletons', years that do not belong to the group immediately before or after them. As such they were omitted from the calculations (Legendre et al. 1985). It can be con- cluded that 1979 and (especially) 1988 comprised major breakpoints in the biological data.

\section{Environmental data}

Finally, the results of chronological clustering applied to the environmental variables are presented in Fig. 12. The results revealed 1977 and 1989 as the major breakpoints for the environmental data. It is 


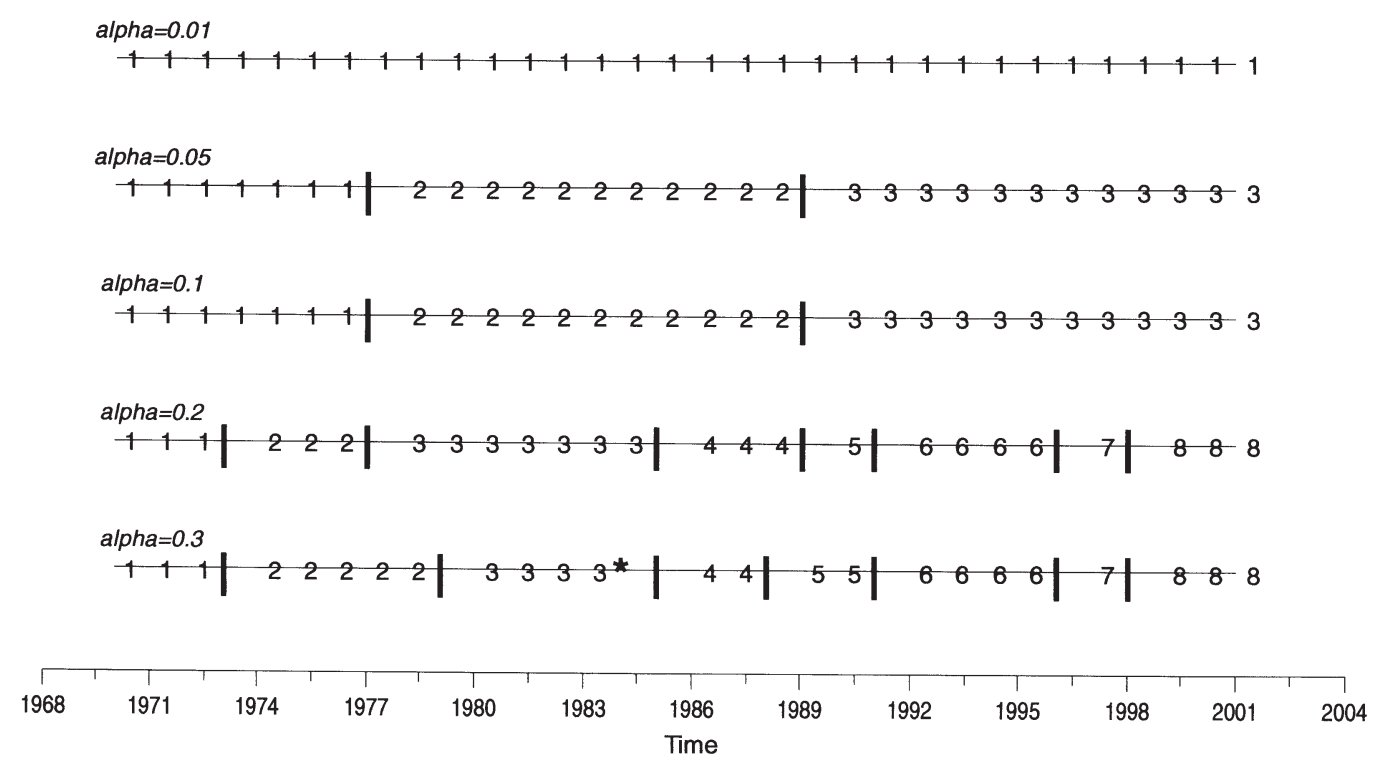

Fig. 12. Results of chronological clustering applied to the environmental variables. Small values of alpha show the most important breakpoints (indicated by vertical lines). Numbers correspond to groups of years. *: 'singletons', years that do not belong to the group immediately before or after them and were thus omitted from the calculations

interesting that for alpha $=0.01$ the algorithm identified all years as 1 group, meaning that the grouping appears at a slightly more detailed level.

\section{DISCUSSION}

Following the approach of Hare \& Mantua (2000), we identified possible regime shifts in the North Sea/ Wadden Sea ecosystem in 1979 and 1988. Firstly, we substantiated those apparent shifts using principal component analysis (PCA). PCA is an appropriate technique if linearity can be assumed (McCune \& Grace 2002). To linearize the relationships, we log-transformed the biotic variables. Linearity can be checked in various ways, for example by pairplots or scatterplots, or by using coenoclines (Gauch 1982). The latter tool is applied as follows: (1) Apply PCA and extract the components. (2) Calculate smoothing curves for each species along each component. The smoothing curves along a PC are called 'coenoclines' (Gauch 1982). If the smoothing curves are approximately linear, then the relationships are approximately linear and PCA should be used instead of correspondence analysis or detrended correspondence analysis (Jongman et al. 1995). The software package Brodgar (available at: www. brodgar.com) automatically calculates these coenoclines, and the results for our data indicated that relationships were indeed approximately linear. This is also confirmed by the results of our initial data exploration using pairplots and scatterplots.
Secondly, we employed the regime shift analysis (RSA) of Ebbesmeyer et al. (1991) to corroborate the timing of the shifts. By its nature, PCA requires a large element of subjective interpretation, but our results are certainly highly consistent with the idea that meaningful regime shifts occurred in the late 1970s (1978 or 1979) and late 1980s (1988 or 1989).

Thirdly, because of the ongoing discussion as to whether RSA is an appropriate statistical technique to identify breakpoints, we also applied chronological clustering. The results obtained by this method confirmed the results of RSA and PCA. We even applied a 4 th statistical technique, namely discriminant analysis (DA). The results are not presented here, but they indicated a statistical significant difference (when assuming normality) between the interactions of the variables in the 3 time periods: 1970 to 1979,1980 to 1988 and 1989 to 1997 . When the normality assumption does not hold, then DA still shows separation of the 3 regimes, although the word 'significant' can no longer be used.

Thus, based on 4 different statistical techniques, we found strong evidence of regime changes in 1979 and 1988, although the exact timing of the breakpoints is not clear-cut. Causal relations and hence the nature of the changes could not be determined by the methods used, but it is possible to conclude which variables are most strongly related to the patterns observed.

The 2 apparent regime shifts were both upwards, i.e. the second shift in 1988 did not return the ecosystem to the pre-1979 situation, but changed it again by an 
overall increase in mean annual values. Therefore, there appears to have been an overall upwards trend in environmental and ecological variables largely determined by 2 sudden upward shifts. Considering the contribution of all variables to the 2 regime shifts (Fig. 9), it is clear that the shift was not caused by a certain identifiable subset of variables; on the other hand, not all variables contributed to the steps (some variables had values close to zero). Furthermore, it is obvious that predominantly biological time series contributed to the larger average step-magnitude. These results suggest that feedbacks such as nutrient availability or selective grazing could be stabilizing the community in a certain state; but are environmental events the trigger? To answer this we need to examine the data in more detail.

\section{Regime shift in 1979}

\section{Environmental variables}

The solar constant showed the greatest difference in the 1979 shift of the environmental variables (Table 4). The reconstructed solar constant (http://climexp.knmi. $\mathrm{nl} /$ ) exhibited an oscillating pattern with cycles of $\sim 11$ yr (comparable with the sunspot cycle), and a gradual increase in values since 1900. Apart from the probable anthropogenic causes for increases in global temperature, the amount of solar irradiance may also be a contributing factor: when the solar constant cycle is in its increasing phase, it may trigger changes in other climate indices as well, with the overall effect of a large-scale drastic environmental alteration. The influence of the sun (sunspot/solar constant) has been controversial since the early 1990s, when 2 Danish researchers showed a direct relationship between sunspot number and global temperature (Friischristensen \& Lassen 1991). The role of the sun in the earth's climate remains the subject of much debate (Pap et al. 2002, Rind 2002, Solanki 2002). Our results suggest that changes in the solar constant were a factor in both ecosystem shifts, albeit its influence appeared to be much less in the 1988 shift.

The second highest difference in the 1979 regime shift was in the East Atlantic (EA) teleconnection pattern, measured in all but the summer (June, July, August) months. This EA pattern is similar to that of the North Atlantic Oscillation (NAO), except that the pressure locations are more southeasterly compared with the NAO. In addition, the lower latitude-anomaly centre contains a strong subtropical link, reflecting largescale modulations in the strength and location of the subtropical ridge. As for the NAO, the EA pattern entered a positive phase in the late 1970s/early 1980s.
Boberg \& Lundstedt (2002) proposed a relationship between solar wind and the large-scale pressure system in the North Atlantic. This relation could be reflected in the shift in the EA pattern in 1979.

The mean high tide in the Wadden Sea also showed a large step-magnitude in 1979, possibly influenced by an increase in wind speed (Dijkema 1997). This could be related to the atmospheric pressure change which, in turn, could be related to solar wind (Boberg \& Lundstedt 2002). The high step-magnitudes found in the salinity of the North Sea and Wadden Sea are obviously related to the great salinity anomaly which entered the North Sea in 1977 and 1978 (Lindeboom et al. 1995).

\section{Biological variables}

Apart from increased porpoise sightings, a striking phenomenon of the first regime shift was a change in phytoplankton composition. For example, the dinoflagellate Ceratium macroceros was absent from continuous plankton recorder surveys after 1979. Edwards et al. (2002) related this to the salinity anomaly. Simultaneously, the abundance of polychaetes in the western Wadden Sea suddenly increased (Beukema et al. 2002). There was a steep decline in the landing of whiting, possibly coupled to a change in composition of the Atlantic water mass entering the North Sea, while the landing of plaice and the number of recruits of herring increased. In turn, it is likely that a change in the abundance of polychaetes and fish species led to a change in the abundance of worm-eating waders and porpoises, respectively. Coinciding with this was an increase in the number of dark-bellied Brent geese in the whole of western Europe. The biological variables showing a sudden change were not limited either geographically or to any particular trophic level, and therefore support the large-scale regime shift hypothesis.

\section{Regime shift in 1988}

\section{Environmental variables}

The physical variables that showed the greatest step-magnitude in 1988 were all temperature related, indicating a possible relationship between climate and this regime shift. Superimposed on global warming, sudden jumps apparently occurred, which can also be seen in the original time series. The solar constant cycle reached a new minimum in 1987. The subsequent increase could partly have triggered the jump seen in the climate indices. Also coinciding with this 
was the change in the winter NAO index, which increased from 1988 onwards to its highest positive level observed in the 20th century. This resulted in an increased inflow of relatively warm Atlantic water, leading to warm sea-surface temperature and high salinity and possibly also increased nutrient inflow. It has been estimated that $90 \%$ of the nutrients $(\mathrm{P}, \mathrm{N})$ in the North Sea come from the North Atlantic (Edwards et al. 2002). In turn, these sudden changes will have affected the marine ecosystems and thus the biological variables.

\section{Biological variables}

Several fish species showed dramatic changes in abundance, evident in records of non-commercial species like solenet and scald fish and of landings of cod and haddock. Once again the abundance of the dinoflagellate Ceratium macroceros also changed, but this time it increased. Similar to the 1979 shift was the increase in porpoise sightings and the number of Brent geese. Additionally, the relative number of harbour seal pups increased.

Not all variables showed a change coinciding with the 2 regime shifts (see Table 1), e.g. the winter temperature of the Wadden Sea and the landing of sole showed no change during the 1979 shift, while during the 1988 shift, the EA teleconnection pattern, the winter abundance of gastropods, the yield of Norway pout and the seal strandings did not change at all. However, a vast majority of the data series available for this analysis indicated major shifts.

\section{CONCLUSIONS}

For both shifts, environmental variables seemed to trigger a change without themselves displaying a very clear change (e.g. Fig. 8), whereas the biological variables seemed to maintain the situation in a new stable state. These patterns are reflected in the great resemblance between the PC scores of the biological time series only and of all variables combined, and the low year-to-year variability in the biological data sets. However, it should be kept in mind that all time series made an equal contribution to the calculations and that we had twice as many biological time series as environmental time series.

To summarise possible environmental triggers of the shifts of 1979 and 1988, the first seemed to be related to salinity and possibly weather conditions, whereas the second could be related to weather and, more specifically, temperature. Therefore, it appears possible that ocean climate conditions have had far-reaching conse- quences on the ecology of the North Sea, but at present it is not possible to say what the primary cause(s) of these conspicuous ecosystem shifts were. Lindeboom (in press) hypothesizes that there may be a combination of factors, a complex interaction between ocean, climate, anthropogenic perturbations and atmospheric oscillations, each having a varying degree of importance. The spatial and temporal scales of measured variables play an important role in the types of shifts they can reflect. Variables that have the ability to respond instantly, such as phytoplankton, temperature and spatial distribution of larger organisms, can show sudden jumps while changes in other variables, such as age distributions, biomass and abundance of larger organisms, are reflected more by a lag phase or by longer-term trends.

Our results indicated a number of patterns similar to Hare \& Mantua's (2000) study of the North Pacific, including an overall trend with sudden changes superimposed, and that those state-shifts are reflected more consistently by biological time series rather than by physical indices. However, certain differences were found between the 2 studies, including the years of change and the importance of the climate indices. In the North Pacific, the first regime shift apparently took place in 1977, and the second in 1989, whereas we found that the biggest changes in North Sea and Wadden Sea took place in 1979 and 1988. In the North Pacific, the 1977 regime shift was apparently triggered by climate indices, whereas we found the influence of these factors to be stronger in the 1988 shift. The great similarity between the 2 studies, however, could indicate that the climate-ocean interaction, including marine biological processes, changed in the whole of the temperate Northern Hemisphere with a lag phase in NW Europe in the first regime shift and a lag-phase in the North Pacific in the second regime shift. The occurrence of jumps has also been found in other ecosystems. Scheffer et al. (2001) found that gradual changes in the ecosystems of lakes, coral reefs, forests and arid lands can be interrupted by sudden drastic switches to contrasting states. The fact that the observed regime shifts occurred more or less simultaneously in both the North Sea and Wadden Sea, and in the North Pacific, supports the hypothesis of some common causes, such as ocean-climate changes. It is obvious that physical indices have a large influence, but this influence requires further research if it is to become predictable.

Acknowledgements. We are most grateful to Geert Aarts for statistical advice and to Ivor Williams for his comments on earlier drafts of this article. Furthermore, we wish to thank all the researchers and institutes named in Appendix 2 who very kindly supplied us with their original data series. 


\section{LITERATURE CITED}

Alheit J, Hagen E (1996) The Bohuslän herring periods: are they controlled by climate variations or local phenomena? Int Counc Explor Sea Comm Meet 6:21

Austen MC, Buchanan JB, Hunt HG, Josefson AB, Kendall MA (1991) Comparison of long-term trends in benthic and pelagic communities of the North Sea. J Mar Biol Assoc UK 71:179-190

Beare DJ, McKenzie E (1999) Temporal patterns in the surface abundance of Calanus finmarchicus and C. helgolandicus in the northern North Sea (1958-1996) inferred from continuous plankton recorder data. Mar Ecol Prog Ser 190:241-251

Beare DJ, Batten S, Edwards M, Reid DG (2002) Prevalence of boreal Atlantic, temperate Atlantic and neritic zooplankton in the North Sea between 1958 and 1998 in relation to temperature, salinity, stratification intensity and Atlantic inflow. J Sea Res 48:29-49

Beaugrand G, Reid PC, Ibanez F, Lindley JA, Edwards M (2002) Reorganization of North Atlantic marine copepod biodiversity and climate. Science 296:1692-1694

Bell MA, Legendre P (1987) Multicharacter chronological clustering in a sequence of fossil sticklebacks. Syst Zool 36:52-61

Bergman M, Lindeboom H (1999) Natural variability and the effects of fisheries in the North Sea: towards an integrated fisheries and ecosystem management? In: Gray J (ed) Biogeochemical cycling and sediment ecology. Kluwer Academic Publishers, Dordrecht, p 173-184

Beukema J (1990) Expected effects of changes in winter temperatures on benthic animals living in soft sediments in coastal North Sea areas. In: Beukema J (ed) Expected effects of climate change on marine coastal ecosystems. Kluwer Academic Publishers, Dordrecht, p 83-92

Beukema JJ, Essink K, Dekker R (2000) Long-term observations on the dynamics of three species of polychaetes living on tidal flats of the Wadden Sea: the role of weather and predator-prey interactions. J Anim Ecol 69:31-44

Beukema JJ, Cadee GC, Dekker R (2002) Zoobenthic biomass limited by phytoplankton abundance: evidence from parallel changes in two long-term data-series in the Wadden Sea. J Sea Res 48:111-125

Boberg F, Lundstedt H (2002) Solar wind variations related to fluctuations of the North Atlantic Oscillation. Geophys Res Lett 29:310-313

Bradley DC, Ormerod SJ (2001) Community persistence among stream invertebrates tracks the North Atlantic Oscillation. J Anim Ecol 70:987-996

Burroughs W (1992) Weather cycles real or imaginary? Cambridge University Press, Cambridge

Cadée GC, Hegeman J (1991a) Historical phytoplankton data of the Marsdiep. Hydrobiol Bull 24:111-118

Cadée GC, Hegeman J (1991b) Phytoplankton primary production, chlorophyll and species composition, organic carbon and turbidity in the Marsdiep in 1990, compared with foregoing years. Hydrobiol Bull 25:29-35

Cadée GC, Hegeman J (2002) Phytoplankton in the Marsdiep at the end of the 20th century; 30 years monitoring biomass, primary production, and Phaeocystis blooms. J Sea Res 48:97-110

Colijn F (1991) Changes in plankton communities: when, where and why? ICES Mar Sci Symp 195:193-212

Daan N (2000) De Noordzee-visfauna en criteria voor het vaststellen van doelsoorten voor het natuurbeleid. Netherlands Institute for Fisheries Research (RIVO), IJmuiden

Daan N, Heessen H, Pope J (1994) Changes in the North Sea cod stock during the twentieth century. ICES Mar Sci Symp 198:229-243

Dickson RR, Meincke J, Malberg SA, Lee V (1988) The great salinity anomaly in the northern North Atlantic 1968 to 1982. Prog Oceanogr 20:103-151

Dickson RR, Colebrook J, Svendsen E (1991) Recent changes in the summer plankton of the North Sea. ICES Mar Sci Symp 195:232-242

Dijkema KS (1997) Impact prognosis for salt marshes from subsidence by gas extraction in the Wadden Sea. J Coast Res 13:1294-1304

Ebbesmeyer C, Cayan D, McLain D, Nicols F, Peterson D, Redmond K (1991) 1976 step in the Pacifc climate: forty environmental changes between 1968 and 1975 and 1977 and 1984. In: Betancourt JL, Tharp VL (eds) Proceedings of the Seventh Annual Climate (PACLIM) Workshop, April 1990. Interagency Ecol Studies Prog Tech Rep No 26, California Department of Water Resources, Sacremento, CA, p 115-126

Edwards M, Reid P, Planque B (2001) Long-term and regional variability of phytoplankton biomass in the north-east Atlantic (1960-1995). ICES J Mar Sci 58:39-49

Edwards M, Beaugrand G, Reid PC, Rowden AA, Jones MB (2002) Ocean climate anomalies and the ecology of the North Sea. Mar Ecol Prog Ser 239:1-10

Ellett D, Blindheim J (1992) Climate and hydrographic variability in the ICES area during the 1980s. In: Dickson RR (ed) Hydrological variability in the ICES area, 1980-1989. ICES Mar Sci Symp 195:11-31

Fox CJ, Planque BP, Darby CD (2000) Synchrony in the recruitment time-series of plaice (Pleuronectes platessa L) around the United Kingdom and the influence of sea temperature. J Sea Res 44:159-168

Fransz H, Gonzalez S, Cadée G, Hansen F (1992) Long-term change of Temora longicornis (Copepoda, Calanoida) abundance in a Dutch tidal inlet (Marsdiep) in relation to eutrophication. Neth J Sea Res 30:23-32

Frid CLJ, Clark RA, Hall JA (1999) Long-term changes in the benthos on a heavily fished ground off the NE coast of England. Mar Ecol Prog Ser 188:13-20

Friischristensen E, Lassen K (1991) Length of the solarcycle-an indicator of solar-activity closely associated with climate. Science 254:698-700

Fromentin JM, Ibanez F, Dauvin JC, Dewarumez JM, Elkaim B (1997) Long-term changes of four macrobenthic assemblages from 1978 to 1992. J Mar Biol Assoc UK 77:287-310

Furnes GK (1992a) Long-term variability of the in-out flow to the North Sea. In: Dickson RR (ed) Hydrological variability in the ICES area, 1980-1989. ICES Mar Sci Symp 195: 103-109

Furnes GK (1992b) Climatic variations of oceanographic processes in the north European Seas - a review of the $1970 \mathrm{~s}$ and 1980s. Cont Shelf Res 12:235-256

Gauch HG (1982) Multivariate analysis in community ecology. Cambridge University Press, Cambridge

Gulev SK, Hasse L (1999) Changes of wind waves in the North Atlantic over the last 30 years. Int J Climatol 19:1091-1117

Hare SR, Mantua NJ (2000) Empirical evidence for North Pacific regime-shifts in 1977 and 1989. Prog Oceanogr 47: 103-145

Hare SR, Mantua NJ (in press) Comment on 'red noise and regime-shifts' by D Rudnick and RE Davis. Deep-Sea Res

Hastie TJ, Tibshirani RJ (1990) Generalized additive models. Chapman \& Hall, London

HCCPR (Hadley Centre for Climate Prediction and Research) (2002) Digest of environmental statistics, Department for Environment, Food and Rural Affairs, Exeter 
Hickel W, Berg J, Treutner K (1992) Variability in phytoplankton biomass in the German Bight near Helgoland, 1980 to 1990. ICES Mar Sci Symp 195:249-259

IJnsen F (1988) Het karakteriseren van winters. Zenit 15: $50-55$

Jolliffe IT (2002) Principal component analyses, 2nd edn. Springer-Verlag, New York

Jongman RHG, Ter Braak CJF, Van Tongeren OFR (1995) Data analysis in community and landscape ecology. Cambridge University Press, Cambridge

Josefson AB, Jensen JN, Aertebjerg G (1993) The benthos community structure anomaly in the late 1970s and early 1980 s - a result of a major food pulse. J Exp Mar Biol Ecol 172:31-45

Kristjánsson J (2001) On the length of the solar cycle and the Earth's climate. Cicerone 1:1-2

Kröncke I, Dippner JW, Heyen H, Zeiss B (1998) Long-term changes in macrofaunal communities off Norderney (East Frisia, Germany) in relation to climate variability. Mar Ecol Prog Ser 167:25-36

Lean J, Beer J, Bradley R (1995) Reconstruction of solar irradiance since 1610-implications for climate-change. Geophys Res Lett 22:3195-3198

Legendre P, Legendre L (1998) Numerical ecology, 2nd edn. Elsevier, Amsterdam

Legendre P, Dallot S, Legendre L (1985) Succession of species within a community: chronological clustering, with application to marine and freshwater zooplankton. Am Nat 125: $257-288$.

Lindeboom HJ (in press) Comparison of effects of fishing with effects of natural events and non-fishing anthropogenic impacts on benthic habitats. In: Barnes PW, Thomas JP (eds) Benthic habitats and the effects of fishing. American Fisheries Society, Bethesda, MD

Lindeboom H, Raaphorst Wv, Beukema J, Cadée G, Swennen C (1995) (Sudden) Changes in the North Sea and Wadden Sea: oceanic influences underestimated? Dtsch Hydrogr Z 2:86-100

Lindley JA, Batten SD (2002) Long-term variability in the diversity of North Sea zooplankton. J Mar Biol Assoc UK 82:31-40

Lindley JA, Gamble JC, Hunt HG (1995) A change in the zooplankton of the central North Sea $\left(55\right.$ to $\left.58^{\circ} \mathrm{N}\right)-$ a possible consequence of changes in the benthos. Mar Ecol Prog Ser 119:299-303

Loewe P, Becker G (2003) North Sea SST since 1968: some gross statistics contribution to 2003 report of the ICES Working Group on Oceanic Hydrography (WGOH). Bundesamt für Seeschifffahrt und Hydrographie, Hamburg

McCune B, Grace JB (2002) Analysis of ecological communities. MjM Software, Gleneden Beach, OR

Mironova I, Pudovkin M (2002) Solar activity as a controlling factor of sunshine intensity at low altitudes. Int J Geomagnetism Aeronomy 3:87-90

Mork KA, Blindheim J (2000) Variations in the Atlantic inflow to the Nordic Seas, 1955 to 1996. Deep-Sea Res 47: 1035-1057

Nesme-Ribes E, Baliunas S, Skoloff D (1996) The stellar dynamo: sunspot cycles-on other stars-are helping astronomers study the sun's variations and the ways they might affect the earth. Sci Am Aug:30-36

Neudecker T, Damm U (1996) Abundance indices of brown shrimp (Crangon crangon L) at the west coast of Schleswig-Holstein, North Sea. Int Counc Explor Sea Shellfish Comm 1996/K 8:18

Nierman U (1996) Fluctuations and mass occurrence of Phoronis mülleri (Phoronidea) in the south-eastern North
Sea during 1983 to1988. Senckenb Marit 28:53-63

OJaveer H (1996) Changes in the fish community of the Gulf of Riga during the last two decades. Int Counc Explor Sea Comm Meet Baltic Fish Comm 1996/J 16:13

Ottersen G, Planque B, Belgrano A, Post E, Reid PC, Stenseth NC (2001) Ecological effects of the North Atlantic Oscillation. Oecologia 128:1-14

Otto L, Zimmerman JTF, Furnes GK, Mork M, Saetre R, Becker G (1990) Review of the physical oceanography of the North Sea. Neth J Sea Res 26:161-238

Pap J, Frohlich C, Kuhn J, Sofia S, Ulrich R (2002) A discussion of recent evidence for solar irradiance variability and climate. Adv Space Res 29:1417-1426

Philippart CJM, Lindeboom HJ, van der Meer J, van de Veer HW, Witte JI (1996) Long-term fluctuations of fish recruit abundance in the western Wadden Sea in relation to variation in the marine environment. ICES J Mar Sci 53: 1120-1129

Philippart C, Andersin A, Laine A, Lindeboom H, Piet $\mathrm{G}_{\text {, }}$ Rijnsdorp A, van Storch H, Zorita E (2000) Variability within marine ecosystems of northwestern Europe. Final report EC-DGXIV research contract FAIR 95 7710 . Netherlands Institute for Sea Research (NIOZ), Den Burg, Texel

Pierce GJ, Boyle PR (2003) Empirical modelling of interannual trends in abundance of squid (Loligo forbesi) in Scottish waters. Fish Res 59:305-326

Pinnegar JK, Jennings S, O'Brien CM, Polunin NVC (2002) Long-term changes in the trophic level of the Celtic Sea fish community and fish market price distribution. J Appl Ecol 39:377-390

Reid PC, Edwards M, Hunt HG, Warner AJ (1998) Phytoplankton change in the North Atlantic. Nature 391: 546-546

Reid PC, Borges MD, Svendsen E (2001a) A regime-shift in the North Sea circa 1988 linked to changes in the North Sea horse mackerel fishery. Fish Res 50:163-171

Reid PC, Holliday NP, Smyth TJ (2001b) Pulses in the eastern margin current and warmer water off the northwestern European shelf linked to North Sea ecosystem changes. Mar Ecol Prog Ser 215:283-287

Reijnders PJH (1981) Management and conservation of the harbour seal (Phoca vitulina) population in the international Wadden Sea area. Biol Conserv 19:213-221

Reijnders PJH, Brasseur S (2003) Veränderungen in Vorkommen und Status der Bestände von Seehunden und Kegelrobben in der Nordsee-mit Anmerkungen zum Robbensterben 2002. In: Lozán L, Rachor E, Reise K, Sündermann J, von Westernhagen H (eds) Warnsignale aus der Nordsee und Wattenmeer-eine aktuelle Umweltbilanz. Wissenschaftliche Auswertungen, Hamburg, p 330-339

Reijnders PJH, Ries EH, Tougaard S, Norgaard N, Heidemann G, Schwarz J, Vareschi E, Traut IM (1997) Population development of harbour seals Phoca vitulina in the Wadden Sea after the 1988 virus epizootic. J Sea Res 38: 161-168

Rind D (2002) Climatology — the sun's role in climate variations. Science 296:673-677

Rogers J (1984) The association between the North Atlantic Oscillation and the Southern Oscillation in the northern hemisphere. Mon Weather Rev, Am Meteorol Soc 112: 1999-2015

Rudnick DL, Davis RE (2003) Red noise and regime-shifts. Deep-Sea Res I 50:691-699

Scheffer M, Carpenter S, Foley JA, Folke C, Walker B (2001) Catastrophic shifts in ecosystems. Nature 413: 591-596 
Siegismund F, Schrum C (2001) Decadal changes in the wind forcing over the North Sea. Clim Res 18:39-45

Sims DW, Genner MJ, Southward AJ, Hawkins SJ (2001) Timing of squid migration reflects North Atlantic climate variability. Proc R Soc Lond Ser B 268:2607-2611

Solanki SK (2002) Solar variability and climate change: is there a link? Astron Geophys 43:9-13

Southward AJ, Hawkins SJ, Burrows MT (1995) 70 years observations of changes in distribution and abundance of zooplankton and intertidal organisms in the western English channel in relation to rising sea temperature. J Therm Biol 20:127-155

Editorial responsibility: Otto Kinne (Editor-in-Chief), Oldendorf/Luhe, Germany
Sunspot Index Data Centre (SIDC) (2003) World data centre for the sunspot index. Royal Observatory of Belgium, Brussels Svendsen E, Magnusson A (1992) Climatic variability in the North Sea. In: Dickson RR (ed) Hydrological variability in the ICES area, 1980-1989. ICES Mar Sci Symp 195: $144-158$

Swennen C (1991) Fledgling production of eiders Somateria mollisima in the Netherlands. J Ornithol 132:427-437

Zheng X, Pierce GJ, Reid DG, Jolliffe IT (2002) Does the North Atlantic current affect spatial distribution of whiting? Testing environmental hypotheses using statistical and GIS techniques. ICES J Mar Sci 59:239-253

Submitted: October 24, 2003; Accepted: November 25, 2004 Proofs received from author(s): July 12, 2005 